\title{
EL DONANTE APRENDIZ DE MAGO EN LAS EPIFANÍAS MEDIEVALES. ALGUNAS ACOTACIONES EN CONTEXTOS ARTÍSTICOS HISPÁNICOS Y EUROPEOS
}

\author{
POR \\ Rosa Alcoy Pedrós \\ Universitat de Barcelona
}

\begin{abstract}
Son numerosas las representaciones del donante que hallan un punto de referencia en la Adoración de los reyes de Oriente. Por este camino es lícito interpretar algunas de las imágenes del arte de época medieval y moderna que hacen comparecer al donante ante la Virgen y el Niño como renovadas epifanías (o nuevas epifanías). Su sentido puede apoyarse en un notorio elenco de textos medievales que revelan la existencia de contenidos similares o análogos entre distintos tipos de escenas. Este trabajo recopila y revisa sobre todo aquellas obras que, al situar al donante arrodillado o en oración junto a los reyes de la Epifanía histórica, mejor evidencian su conversión en aprendiz de rey mago.
\end{abstract}

Palabras clave: Arte medieval; Epifanía; Reyes magos; Donante; Iconografía; Modelos.

There are numerous representations of the donor shown in relation to the Adoration of the Magi. Thus it is legitimate to interpret certain Medieval and Renaissance images in which the donor appears along with the Virgin and Child as renewed or new Epiphanies. This interpretation is supported by a notable group of medieval texts, which reveal the existence of similar or analogous contents among different types of scenes. This paper compiles and reviews in particular those works in which the kneeling or praying donor is placed next to the Three Kings, in order to demonstrate his conversion into an apprentice wizard king.

Key words: Medieval Art; Epiphany; The Magi; Donor; Iconography; Models.

\section{Triplex una die manifestatio}

No hace falta ni señalar ni demostrar, por ser un aspecto bien conocido, que la Epifanía como manifestación de la divinidad alcanzó un evidente carácter trinitario formalizado en los presentes 
de los reyes magos ${ }^{1}$. La vocación de los magos revelaba la complejidad del Dios cristiano en la celebración de una festividad muy importante en que se promueve una actuación similar por parte del cristiano, llamado a emular la fe de estos primeros y singulares testimonios y, hasta cierto punto, también a parecerse o equipararse a ellos, estimulado por la aspiración de alcanzar el Paraíso ${ }^{2}$.

Desde muy pronto el espectacular desarrollo del tema de los magos favorecería que algunos donantes y promotores de obras artísticas optaran por hacerse representar orantes ante diversas imágenes de la divinidad, según el esquema definido para aquellos sabios, que fueron convertidos con el paso del tiempo en reyes verdaderos ${ }^{3}$. La Virgen que sostiene a Jesús en sus brazos o falda, tema fundamental de todo arte cristiano, podía extraerse directamente de las Epifanías en un sentido plástico y compositivo al tiempo que figurado y especulativo. Esta maniobra abre la puerta de acceso al contenido, siempre modélico, de la adoración histórica, de modo que se aprovecha su amplia repercusión como paraguas que añade sentido, fondo significante, valores y profundidad al planteamiento gráfico contemporáneo que se relaciona con cada donante. Por tanto, es posible admitir el uso efectivo de una estrategia que alimenta y retroalimenta la representación de los dos temas, aunque sólo en algunos casos se tenga consciencia de todo ello. Madre e Hijo, ubicados frente al donante, componen un argumento distinto que, todavía hoy y en muchos casos, me parece lícito denominar "Epifanía del donante"4 o "Epifanía al donante"5. El juego iconográfico que se deriva de estas operaciones es fruto de una manipulación simple que, sin embargo, se complica bastante una vez canalizada sobre dos ejes emparentados: el de la transposición o suplantación y el del parentesco y la analogía.

Algunas de las ideas que convertirán al donante en aprendiz de mago planean ya sobre los programas de los ábsides del arte italo-bizantino que penetra en la Cataluña del siglo XI, sobre un fondo anterior que nos llevaría a distintas zonas de Italia, y que fragua también en las pinturas murales de los talleres activos en Àger, el Burgal, Àneu o Pedret, entre otros lugares. Sin embargo, la conexión estricta entre la adoración de los magos y la adoración del donante no se advierte todavía explícitamente en estas obras románicas, aunque sea interesante cruzar sus programas y reparar en la figura identificada como Lucía de Pallars, la donante femenina de Sant Pere del Burgal, teniendo muy presente la Epifanía representada como tema principal en la iglesia de Santa María de Àneu (figs. 1-3).

En el terreno de la escultura algunas creaciones del siglo XII registran decididamente la conexión entre reyes y donantes. En Cataluña, hay que recordar el tímpano de la Epifanía de la iglesia de Sant Martí de Mura (fig. 4). Una tosca y gran Virgen en Majestad sostiene a Jesús que,

${ }^{1}$ Este estudio ha disfrutado del soporte de los proyectos I+D del grupo EMAC. Romànic i Gòtic de la Universidad de Barcelona (HUM2005-03961/ARTE), financiados por el Ministerio de Educación y Ciencia y los fondos FEDER y se inserta en la programación del proyecto sobre las migraciones de sentido en el arte europeo del occidente medieval que entronca directamente con el nuevo proyecto de EMAC: "Contextos para el arte catalán medieval desplazado" (HAR2008-01305/ARTE) financiado por el Ministerio de Ciencia e Innovación y los fondos FEDER.

${ }^{2}$ Son numerosas las fuentes textuales medievales que avalan esta idea. Sólo a modo de ejemplo cabe recordar textos como los de San Bernardo, "Sermones del tiempo en la Epifanía del Señor", Obras completas de san Bernardo, I, BAC, Madrid, 1953, pp. 316-318.

3 Para una aproximación a las fuentes de las Epifanías representadas y a su evolución histórica véase CARDINI, Franco, Los reyes magos. Historia y leyenda, Barcelona, 2001 (1993).

4 Alcoy, Rosa, "Acerca de algunas epifanías extemporáneas. La llegada al Otro Mundo y la Iconografía de los Reyes Magos”, Boletín del Museo e Instituto “Camón Aznar”, XXVII, 1987, Zaragoza, pp. 39-65.

5 Bango Torviso, Isidro, "Sobre el origen de la Prosquinesis en la Epifanía a los Magos", Traza y Baza, 1978, pp. 25-36.

${ }^{6}$ Alcoy, Rosa, "Les primeres expressions pictòriques en clau cristiana. Estil i discurs", en Arrels Cristianes. Presència i significació del cristianisme en la història i la societat de Lleida, vol. I, Lleida, 2008, pp. 379-402. 

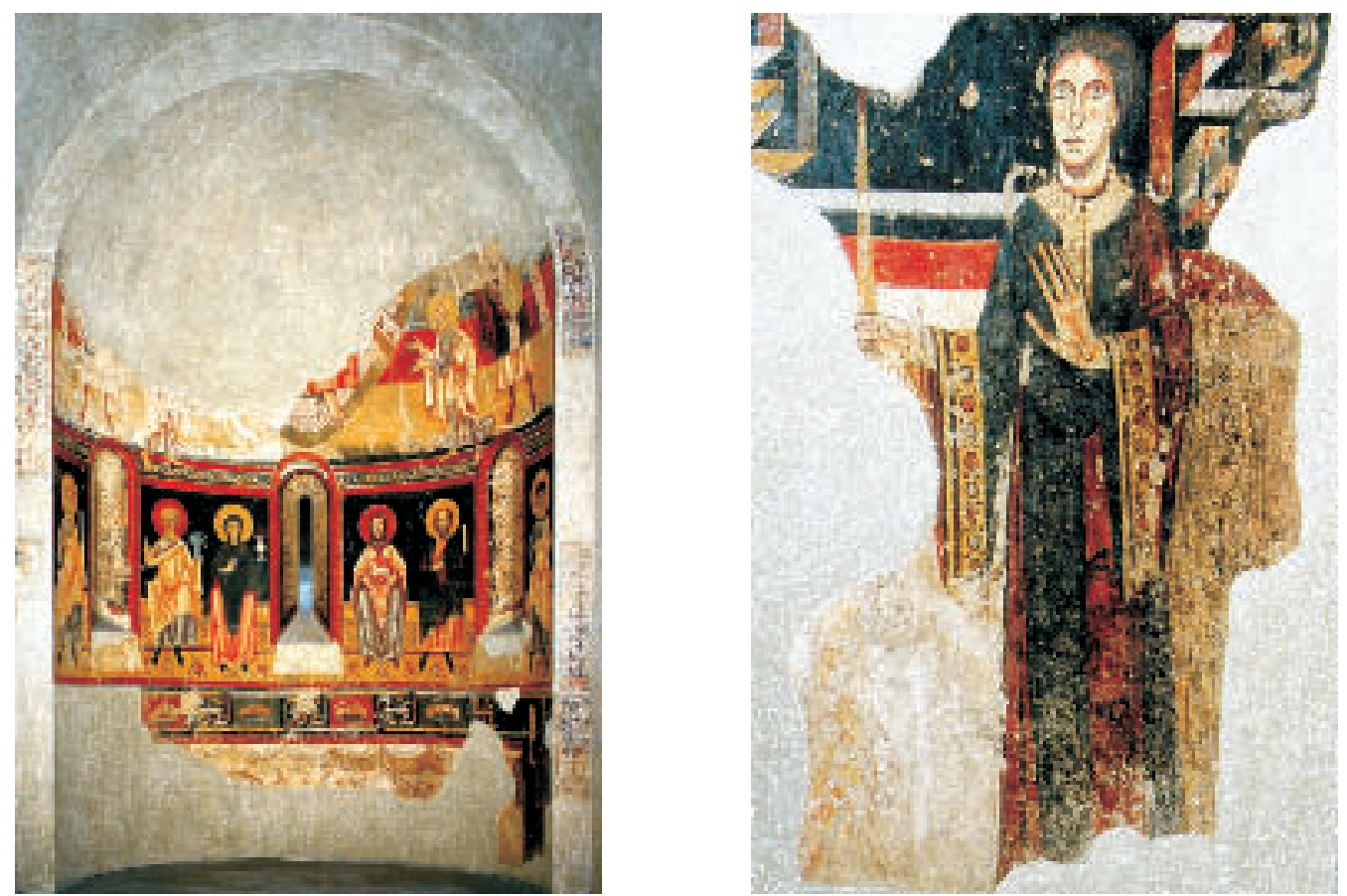

Figs. 1 y 2. Pinturas murales del ábside de Sant Pere del Burgal, Barcelona, MNAC, finales del siglo XI, y Donante femenina.

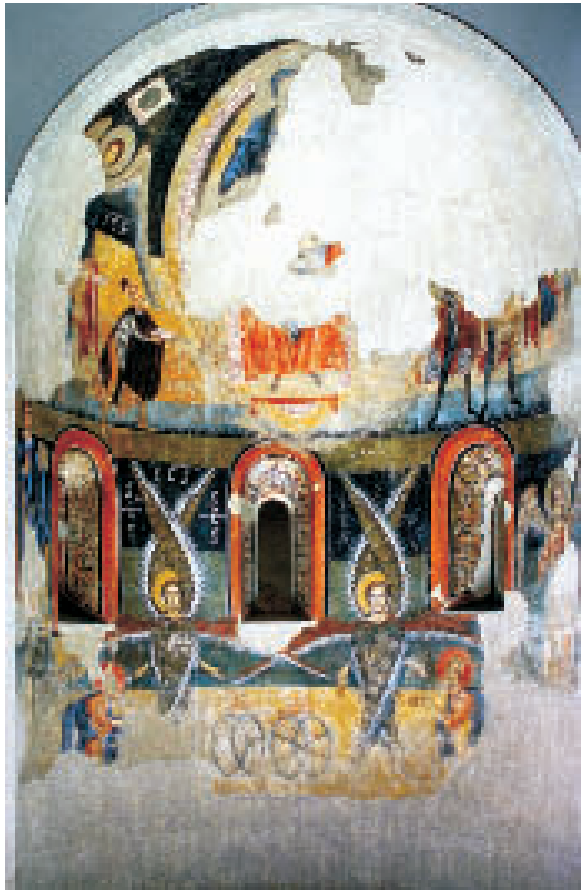

Fig. 3. Pinturas murales del ábside de Santa Maria d’Àneu. Barcelona, MNAC, finales del siglo XI. 
dispuesto frontalmente con nimbo crucífero, bendice y preside el conjunto mientras los magos, en el flanco izquierdo, comparecen como pequeñas figuras dispuestas en hilera. La diferencia de tamaños resulta tan acusada que mientras la Virgen se diría salida de la tabla central de un frontal, el resto de los personajes, incluido san José, tienen dimensiones más acordes con las de las figuras que habrían poblado las escenas laterales de este tipo de obras. Las zonas que dejan libres son ocupadas por sendos ángeles turiferarios que, al margen del episodio narrativo, inciden en la dimensión cultual otorgada al grupo de la Virgen con el Niño, ambos coronados. Junto a san José comparece un último personaje, recluido en el rincón derecho del tímpano. Se han barajado distintas hipótesis de identificación pero, aún asumiendo un razonable margen para la duda, la que nos parece más verosímil es la defendida por Xavier Barral que reconoce en él a un posible donante. Pese a la tosquedad de la escultura, también es pertinente la datación dentro del siglo XII que propuso este autor ${ }^{7}$. El plausible donante es una figura en pie que imita en este sentido a los tres reyes itinerantes que hacen su entrada en escena por el lado opuesto. Que el sujeto lleve un libro en las manos no contradice esta entidad cuando tenemos en cuenta algunos precedentes visibles en la pintura catalana, alusivos a imágenes de clérigos representados según la tradición iconográfica italo-bizantina. Por otra parte, el libro deja una puerta abierta a plausibles referencias visuales a las fuentes escritas que nos hablan de la Epifanía.

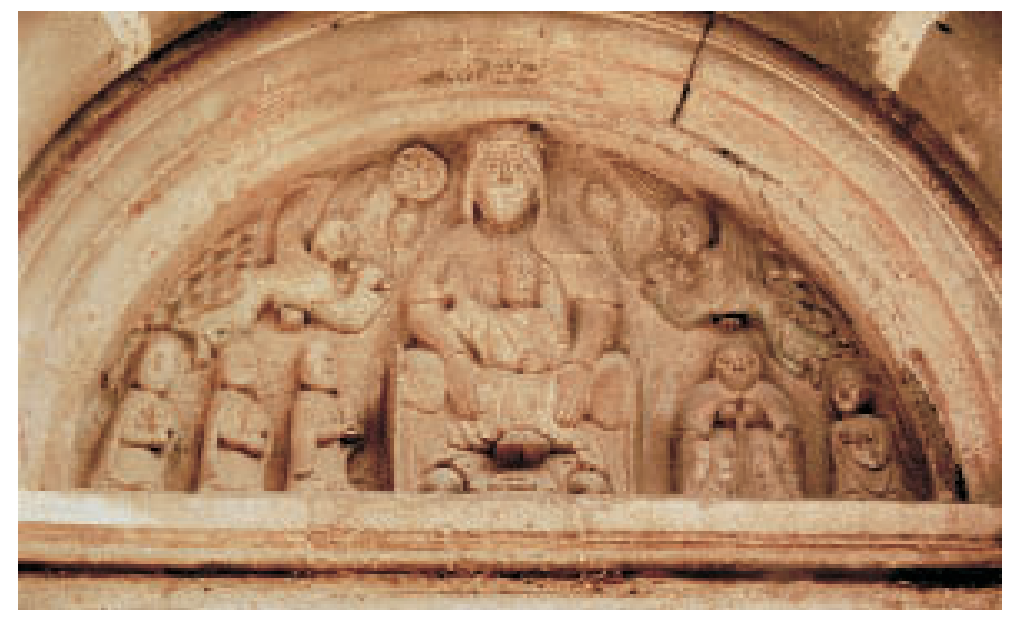

Fig. 4. Tímpano de la Epifanía de la iglesia de Sant Martí de Mura, siglo XII.

Hay que recurrir a otros tímpanos esculpidos para ver ejemplos equivalentes o cercanos, aunque en el deteriorado tímpano conocido para la antigua "abadía" de Manresa, posible referente genérico del Maestro que trabajó en Mura, no se adviertan presencias similares ${ }^{8}$. El tímpano de

7 Barral i Altet, Xavier, "Portada de Sant Martí de Mura", Catalunya romànica. El Bagès, Barcelona, 1984, pp. 324-327.

${ }^{8}$ En Santa María de Uncastillo existe un ejemplo interesante de tímpano con los magos en pie junto a la Virgen y el Niño. En el flanco opuesto se arrodilla un personaje con una larga filacteria en las manos. Para una cronología bastante posterior hay que aludir a toda una serie de tímpanos gallegos dedicados a Epifanías en que comparece el donante: Santa María de Franqueira, Santiago de Compostela, San Fiz de Solivio o San Bieito do Campo, entre los que podemos tener más presentes. El contexto significativo que encuadra estos casos, ya del período gótico avanzado, pudo ser bastante similar al de otras obras a las que atenderemos más adelante. 
la iglesia francesa de Saint Pierre de Mozac (o Mozat) ejemplifica el peso alcanzado por las presentaciones del donante ante la Virgen y el Niño y transparenta los clichés utilizados a partir de las adoraciones de los magos (fig. 5). La Virgen se dispone en el centro de forma semejante en uno y otro caso y tanto ella como Jesús se presentan coronados y ausentes de cuanto sucede a su entorno. El espacio restante es ocupado por figuras nimbadas que, portadoras de libros, báculos y otros atributos, acompañan a un personaje en prosquinesis, emplazado en la zona izquierda del tímpano, a la derecha de la Virgen. El más sobresaliente de los acompañantes es san Pedro, siendo ésta una elección que, vinculada al titular de la iglesia, también es pertinente recuerdo de las bulas papales que situaban la abadía de Mozac bajo la especial protección de la Santa Sede $^{9}$. Éstas se dieron ya en tiempos de Eustache de Montboissier (1131-1147), hermano del abad de Cluny Pedro el Venerable, una buena garantía de las relaciones de Mozac con Roma. La Epifanía de los magos no se registra en esta ocasión, pero la suma de los distintos elementos en juego sugiere la persistente incidencia del episodio bíblico en los planteamientos asociados a los donantes, vistos como nuevos magos desde muy pronto. En Mozac, por encima de los grupos presididos por la Virgen y el Niño planean de nuevo los ángeles, en este caso pintados, que sugieren la dimensión cultual y litúrgica atribuida por encima de todo a la presencia de Madre e Hijo ${ }^{10}$.

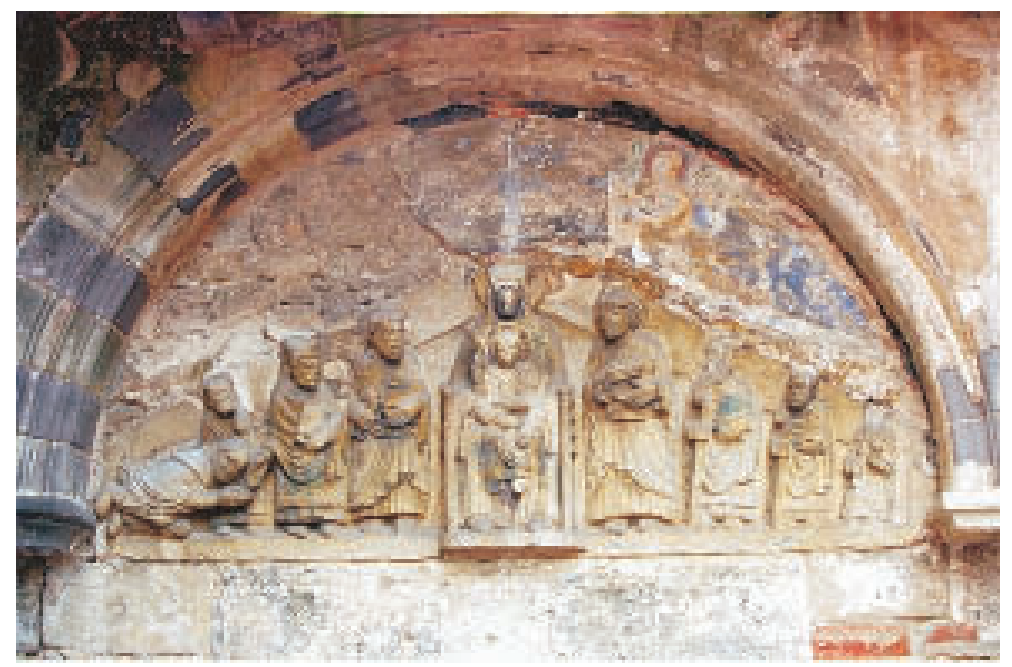

Fig. 5. Tímpano de la iglesia de Saint Pierre de Mozac, siglo XII.

\footnotetext{
${ }^{9}$ Un contexto para el san Pedro de Mozac se dibuja en Quintavalle, Arturo Carlo, "San Pietro 'pellegrino' a Compostela", Medioevo: L'Europe delle Catedrali, Atti del Convegno internazionale di studi di Parma 9, ed. Electa, Milano, 2007, pp. 217-227.

10 Craplet, B., Auvergne romane, Zodiaque, la Nuit des Temps, 1958, fig. 12, p. 208. Z. SwiEChowski, Scupture romane en Auverge, Clermond Ferrand, 1973, es partidario de una cronología cercana al 1100 o de inicios del siglo XII. A este ejemplo podrían añadirse otras obras, a menudo pictóricas, que reclaman la atención sobre el asentamiento de donantes a los pies del grupo sagrado. La catalogación de los múltiples casos dignos de atención queda fuera de los márgenes de este artículo, que tampoco aborda el análisis de las primeras obras conocidas en que los donantes comparecen frente a la Virgen y el Niño, y que nos remiten necesariamente a escenarios italianos y bizantinos.
} 


\section{La puesta en escena del período gótico}

Si estos primeros referentes pudieran considerarse excesivamente ambiguos o poco probatorios de la relación apuntada entre ambos tipos de orantes, el arte gótico europeo nos brinda ejemplos mucho más concluyentes ${ }^{11}$. La Epifanía de los murales trecentistas del claustro de la Abadía de Vezzolano (c. 1340-50) exterioriza la hilación entre la imagen de los reyes de Oriente y el donante al emplazarlos ante una misma imagen de la Virgen y el Niño (fig. 6) ${ }^{12}$. Estas pinturas italianas incluyen la representación del donante y la de los reyes de Oriente en un mismo espacio narrativo. El pintor tiende a equilibrar el tamaño de todos los protagonistas, sin olvidar al donante. Se articula así una relación muy nítida en el plano formal entre la actitud de éste y la acción de los magos, que obliga a Madre e Hijo a repartir su atención. El Niño se ocupa de los reyes y la Virgen se gira y extiende una mano hacia el donante en señal clara de apercibimiento y admisión de su presencia ${ }^{13}$, una forma de hacer explícito el sentido que cabe conferir a sus gestos y a la acogida que será reservada tanto a los magos como al hombre que los imita. Se difunde así una retórica que, conllevada por los reyes y el cristiano, hace posible que éste identifique sus actitudes y gestos con las de los reyes a la espera, lógicamente, de ser correspondido como ellos ${ }^{14}$. La Epifanía y el donante se reúnen en Vezzolano para identificar, en un plano atemporal que saca partido de ciertas analogías, la reverencia del fiel con la acción del mago. El discurso es revelador por no ser demasiado frecuente. Sin embargo, hay que valorar también otros casos, a los que atenderemos algo más adelante, que alcanzan otros lugares de Europa y también el mundo hispánico. Las obras que ahora nos interesan más son las que evidencian el paralelismo icónico entre reyes y donantes. Éste pudo ir bastante más lejos, dado que en la mayoría de las situaciones, por economía de medios o por otras razones más complejas que pretendo analizar en un futuro, se favoreció la exclusión de los magos para situar en su lugar al donante, solo o con sus allegados. Los reyes se convirtieron de este modo en los maestros y modelos de un donante aprendiz de mago.

Para establecer el nexo entre el donante y los reyes se observarán algunas etiquetas formales que permiten que la traslación de sentido se realice sin menoscabo de la entidad y valor otorgado al nuevo episodio (o neo-epifanía). San Vicente Ferrer, en un sermón consagrado a la adoración

\footnotetext{
${ }^{11}$ No son objetivo primordial de este artículo aquellas obras que, aun con un fuerte y emblemático valor epifánico reflejado en otros de mis trabajos sobre el tema, no hacen totalmente explícitos sus planteamientos. Por ejemplo, la fuente bautismal de la capilla de San Jorge de la catedral de Hildesheim o el tímpano de la puerta de Santa Ana de Nôtre Dame de París (siglos XII-XIII, más restauraciones). Se trata de conjuntos muy complejos que, a mi parecer, pueden ser analizados teniendo en cuenta la traslación y actualización de contenidos de la adoración evangélica. Los analizo en Alcoy, Rosa, Anticipaciones del Paraíso. Un estudio sobre la traslación del sentido en el arte del occidente medieval, Barcelona, 2007 (última versión revisada en febrero del 2008).

${ }^{12}$ Las opiniones más optimistas consideran viable una intervención en el claustro en torno al 1300. El ciclo integra el "Encuentro de los tres vivos y los tres muertos" y un Calvario: MotTA, L., "Gli affreschi di Santa Maria de Vezzolano", L'Arte, XIII, 1910; GUERRY, Lilyan, Le thème du thriomphe de la mort dans la peinture italienne, Paris, 1950, pp. 172-173. A esta primera intervención seguiría una segunda de mediados del siglo XIV que ya incluye la Epifanía de los reyes con donante. El conjunto trescentista, abrazado por un arco ojival y mejor conservado que el anterior, integra además una Maiestas Domini rodeada del tetramorfos y una segunda versión del tema del Encuentro. Vid. CHIHAIA, Pavel, Immortalité et décomposition dans l'art du Moyen Âge, Fondation Culturelle roumaine, Madrid, 1988, pp. 43126, figs. 4-5.

13 Toesca, Pietro, La pittura e la miniatura nella Lombardia. Dai piu antichi monumenti alla metà del Quattrocento, Milano, 1912, fig. 207; Pietro Toesca, Il Trecento, Torino, 1951, fig. 665. El sistema de acogida y reparto de protagonismos se repite cuando se representan diversos donantes ante la Virgen y el Niño.

${ }^{14}$ Gombrich, E. H., "Gesto ritualizado y expresión en el arte", La Imagen y el ojo. Nuevos estudios sobre la psicología de la representación pictórica, Madrid, 1987 (1982), pp. 61-74.
} 


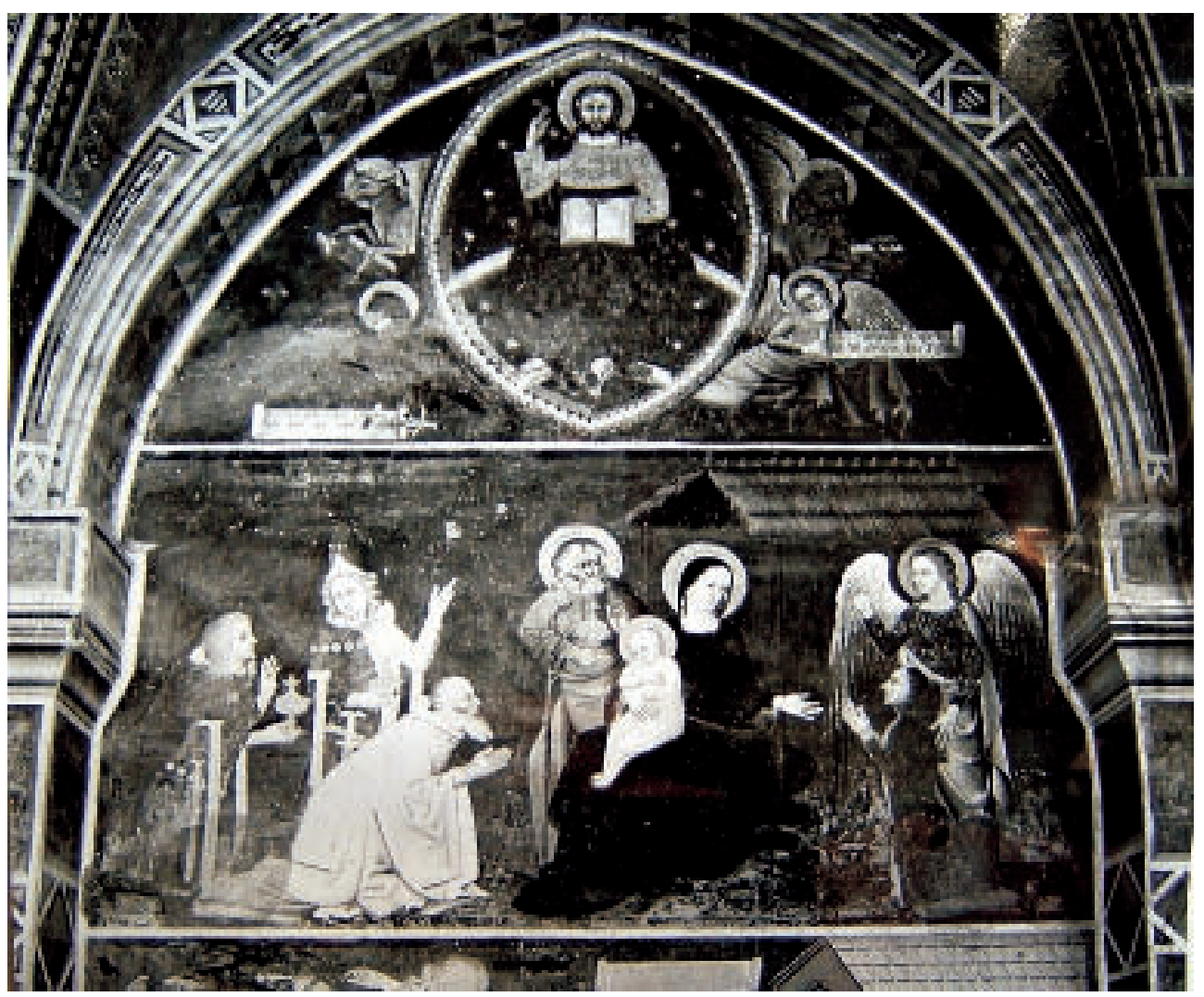

Fig. 6. Murales del Claustro de Santa Maria di Vezzolano (Albugnano, Asti), mediados del siglo XIV. Detalle de la Epifanía con donante.

de los magos, detalla de modo didáctico los modos de la oración del cristiano. El predicador utiliza con soltura la amplia base que le ofrecen la liturgia y los textos bíblicos y patrísticos, avezados en establecer y promover la relación que favorece las comparaciones entre la oración histórica y la oración de los fieles ${ }^{15}$. La Epifanía había concretado un esquema para la adoración que resolvía con éxito y brillantez innegables todas las expectativas creadas a su entorno, al distinguir con claridad un orden para lo terrenal y un orden para lo que debe de corresponder al Cielo. Estas convenciones animaron con naturalidad las artes medievales, sin que ello suponga apartar la figuración del donante de otras escenas y motivos.

En algunos casos, el personaje extemporáneo, el "señor de la obra", se añade a la escena de la Adoración de los reyes, pero sin involucrarse propiamente en ella. Ésta sería la situación del conjunto mural aragonés de la ermita de Nuestra Señora del Monte de Liesa, que nos brinda un ejemplo muy atractivo de las circunstancias que andábamos buscando ${ }^{16}$. En estas pinturas aragonesas varios arcos apuntados enmarcan a la Virgen con el Niño, entronizada y coronada, a los

15 Sant Vicenç Ferrer, Sermons, vol. IV, ed. a cargo de Gret Schib (Els nostres clàssics, col·lecció B), Barcelona,1977, pp. 271-274.

${ }^{16}$ Gudiol, Josep, La pintura medieval en Aragón, CSIC, Zaragoza, 1971, pp. 21 y 72, figs. 64-66. El autor sitúa las pinturas en una cronología imprecisa, algo posterior al 1300. 
reyes magos y a los donantes. Como si se tratara de vidrieras bajo lancetas, las figuras se disponen al lado derecho e izquierdo de la Virgen, que sostiene a Jesús a un lado de la falda. María dirige su mirada a la derecha, donde se encuentran arrodillados cuatro donantes, toda vez que el Niño bendice a los tres reyes del Nuevo testamento que, siguiendo la estrella, comparecen regularmente y con sus presentes por el flanco opuesto ${ }^{17}$. Por consiguiente, se equilibran ambas disposiciones tendentes a remarcar el paradigma que seguirán los fieles, representados por los cuatro personajes orantes, dos hombres y dos mujeres que, algo dañados, no han podido ser identificados con total exactitud. Una inscripción asociada a las pinturas de la ermita de Liesa, en la que se incluyen también interesantes ciclos hagiográficos a modo de retablos murales dedicados a santa Catalina y san Vicente, establece que "aquesta obra primera real el concellio de Liesa la fizo pintar"18.

\section{París y Santa María de Ujué}

La relación de la donante con la Epifanía es distinta en el Libro de Horas de Juana de Navarra (c. 1336-1340, Paris, BNF, ms. lat. 3145) de Jean Le Noir ${ }^{19}$. Este seguidor de Jean Pucelle incluye el rezo de la reina ante la Virgen en una pequeña inicial situada bajo la escena de la Anunciación, un episodio que revisa el planteamiento de las Horas de Jeanne d'Évreux (c. 1325-28) y que no olvida el festejo de los ángeles músicos sobre las cubiertas de la estancia. Si nos fijamos mejor en la pequeña inicial observaremos que el grupo objeto de culto se encuentra situado sobre una estructura soportada por pequeñas columnas a modo de altar (fol. 39). De esta forma, y pese a la bendición que el Niño dirige a la reina Juana, el pintor puede haber querido dar a entender que ésta se arrodilla ante un simulacro, o escultura policroma de Nuestra Señora. Paradójicamente, la escultura cobra vida en la miniatura para establecer comunicación con la reina, pero no pierde por completo su riguroso y preceptivo emplazamiento. Por tanto, nos mantenemos en un terreno ambiguo, que obliga a tener en cuenta otras imágenes orantes de Juana de Navarra dentro del mismo oracional. Una de ellas puede verse también en una " $D$ " bajo la representación de la Trinidad (folio 11), pero la más interesante a nuestros fines es la que sitúa a la gobernante de Navarra sobre la base generada por la orla que rodea el cuadro de la Adoración de los reyes magos (fig. 7) ${ }^{20}$. Además de la figura grotesca, característica de las marginalia de la escuela de Pucelle, que se separa de la orante gracias a una rama vegetal utilizada a tal efecto, hay que reparar en la proximidad de los caballos de los magos y uno de los pajes ocupado en hacerlos permanecer en el establo. La anécdota resulta atrayente por sí misma, pero también porque da curso a la relación entre la Epifanía histórica y la Epifanía diferida o extemporánea que repite su módulo gracias a la figura orante de Juana de Navarra, por más que en este caso no se pueda definir el cuadro completo de la neo-epifanía o Epifanía del donante, ya que la Virgen y el Niño elegidos por la reina, levemente distante, son los mismos que los reyes de Oriente reverencian algo más arriba en la página y algo antes en el tiempo.

${ }^{17}$ El cuarto arco situado a nuestra izquierda parece haber sido ocupado por los caballos de los reyes magos y el sirviente que se ocupa habitualmente de estos animales. De menor tamaño que los restantes personajes, compensan la simetría establecida entre los dos grupos que se aproximan a la Virgen.

18 Deseo agradecer a la profesora María Carmen Lacarra que me hiciese llegar muy oportunamente algunos detalles de estas pinturas; en especial, el que reproduce con gran claridad la inscripción transcrita. Los murales de Liesa, pese a un evidente desgaste y algunas reparaciones, son obra de un gran atractivo que conecta con la cultura plástica septentrional. Otras reproducciones de los murales, posteriores a una reciente restauración, incluyendo una segunda inscripción, pueden verse en www.liesa.info/Asociación Cultural Amigos de Liesa (Jesús Viñuales Borau); www.romanicoaragones.com/ Románico aragonés. La guía digital del arte románico (Antonio García Omedes).

19 Sterling, Charles, La peinture médiévale à Paris 1300-1450, vol. I, Paris, 1987, pp. 104-108.

${ }^{20}$ BAron, Françoise (ed.), Les Fastes du Gothique. Le siècle de Charles V, Paris, 1981, fig. p. 37. 


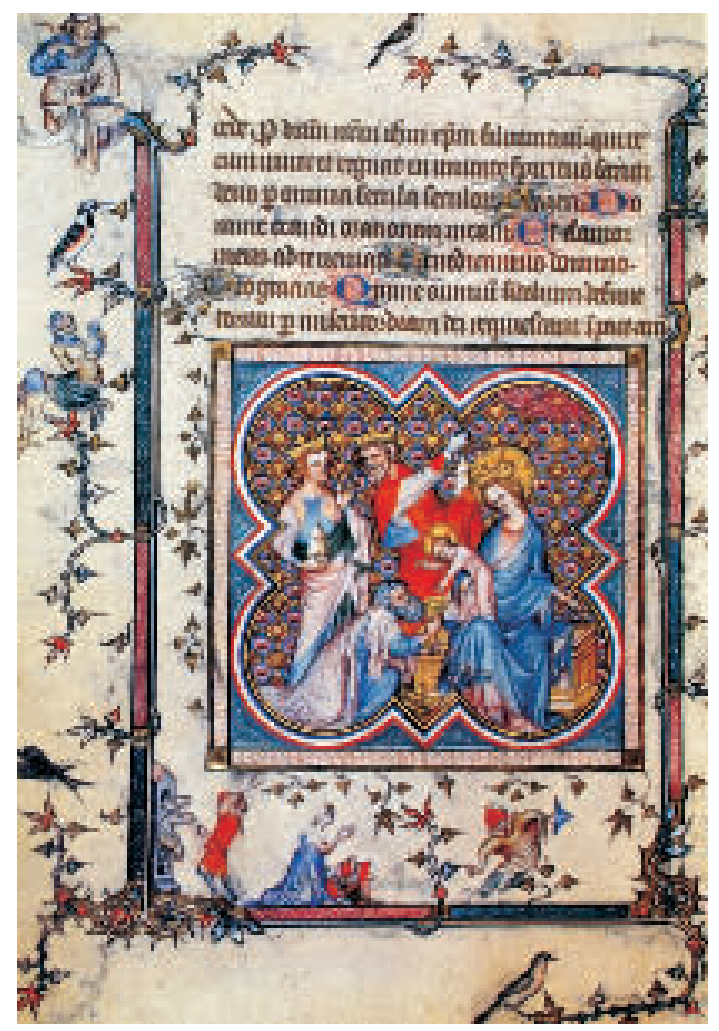

Fig. 7. Jean Le Noir. Horas de Juana de Navarra. Paris, BNF. ms. lat. 3145, c. 1336-1340.

Un cofre eucarístico de mediados del siglo XIV, trabajado en plata dorada y con apreciables esmaltes figurativos, que conserva la Pierpont Morgan Library de Nueva York ${ }^{21}$, proporciona otro ejemplo interesante (fig. 8). En este caso, y también frente a los murales de Liesa, pudiera establecerse cierta relación con un esquema surgido de las vidrieras, o al menos afín a las mismas. Sin embargo, hay que advertir que, como se ha indicado, la composición aragonesa introduce una visión que fuerza a la simetría, totalmente obviada en el cofre esmaltado. En la Epifanía de esta última obra se añade una pequeña orante femenina con hábito, Greta Pfrumbom de Espira, que se acompaña de la inscripción: "PIA DEI GENITRIX S(anct)a MARIA SIS MICHI SEMPER PROPICIA". En diferido, la donante resigue el itinerario de los magos hacia la Virgen y el Niño, añadiéndose tácitamente al cortejo. El valor simbólico de la escena aparece subrayado por la preeminencia conferida a la estrella, que flota sobre la cabeza de la Virgen, y por el león sobre el cual se aposenta el grupo familiar, encajado bajo un primer arco gótico. Un total de seis arcos ritman esta cara del cofre como las lancetas de una vidriera continua. Hacen uso de un esquema que se ha conservado para obras más tardías. Sobresalen entre ellas las magníficas vidrieras de algunas capillas de la catedral de Bourges. En el cofre de Greta de Espira, cuatro de los espacios disponibles son ocupados por los tres reyes y la donante, con lo cual queda todavía un último ambiente a la derecha que bien hubiese podido ser destinado a san José pero que en realidad ha servido para colocar a san

21 Erlande-Brandenburg, Alain, La conquête de l'Europe 1260-1380, Paris, 1987, fig. 266. p. 308. 


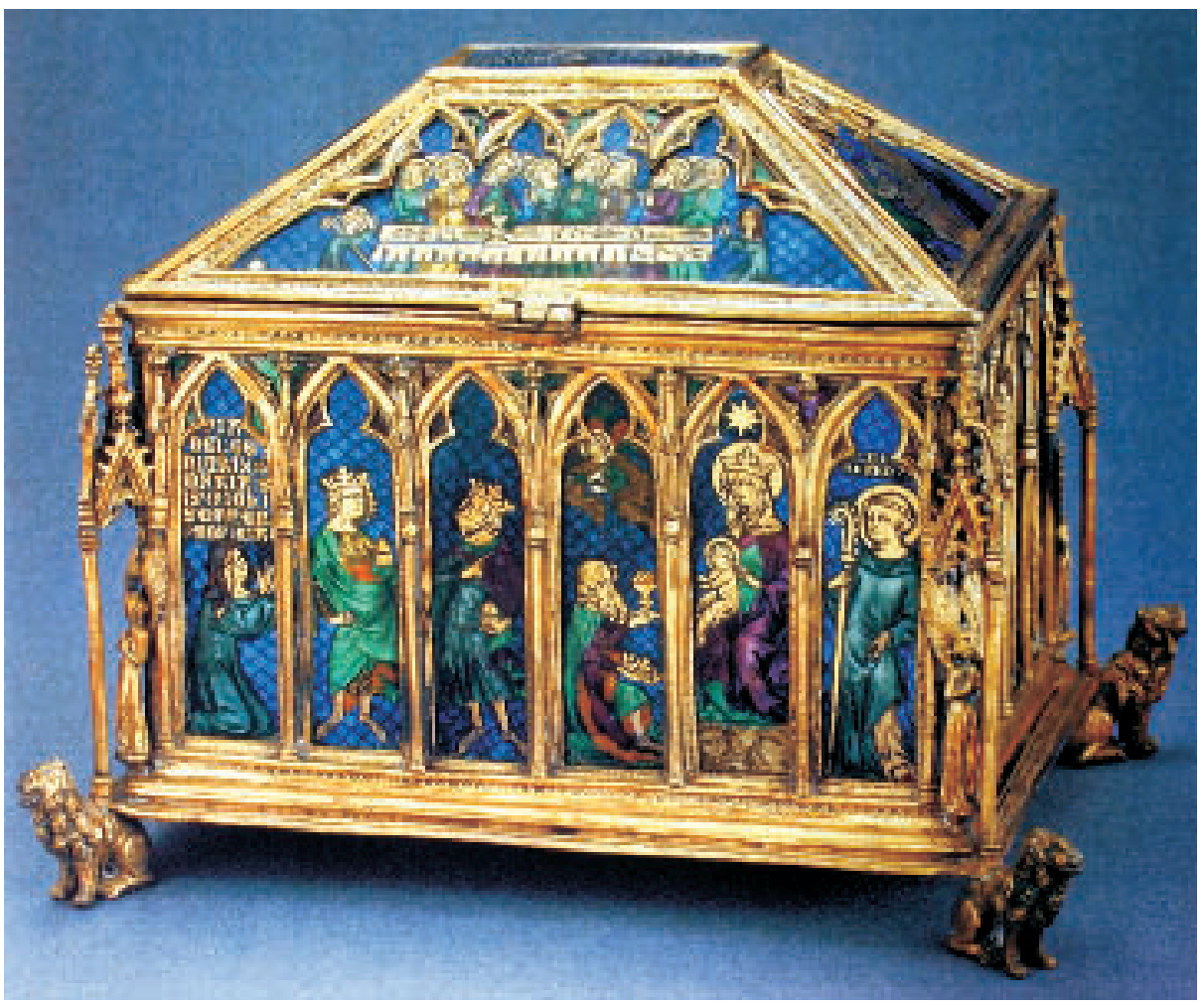

Fig. 8. Cofre eucarístico de Greta Pfrumbom de Espira, New York, Pierpont Morgan Library, mediados del siglo XIV. Epìfanía.

Bernardo. El santo, identificado por una inscripción, comparece como abogado y protector de la orante. Bajo un indumento oscuro de raíz benedictina, muestra su hábito blanco que lo relaciona con los reformados cistercienses. Ambos aspectos son indicativos de la procedencia o destino del cofre, que se localizó en el monasterio benedictino de Liechtenthal (Baden).

En la cubierta, en el mismo lado que la Epifanía, se acomoda la Santa Cena ${ }^{22}$. No parece tratarse de una asociación casual ya que permite recordar la situación paralela que nos procura otro ejemplo relevante: el tímpano de la portada navarra de Santa María de Ujué, donde es la Epifanía la que se levanta sobre la base eucarística propiciada por la Santa Cena ${ }^{23}$. El cofre de la Pierpont

${ }^{22}$ GAuthier, Marie-Madeleine, Émaux du Moyen Âge, Fribourg, 1972, p. 409, cat. n. 224, clasifica el cofre en la región del Rin medio, en Spira, con interrogación. En la caja el tema de los reyes se complementa con la Anunciación, la Presentación al templo y una representación de profetas y apóstoles con filacterias que los identifican. En la cubierta, la Santa Cena encuentra apoyo en prefiguras extraídas del Antiguo Testamento.

${ }^{23}$ Duran i Sanpere, Agustí y Ainaud de Lasarte, Joan, Escultura gótica, Madrid, 1956, fig. 140. La conexión entre Epifanía y eucaristía encontró fundamento de diversas formas. Una de las más conocidas se refiere a celebración de la adoración el mismo día de la bodas de Caná. El episodio, convertido en prefigura de la Santa Cena, destaca por ser uno de los temas que favorece la manifestación de la divinidad de Cristo. No hay que pasar por alto el carácter nupcial del milagro de Caná que alcanza también al tema epifánico. Otro tema asociado a la Epifanía es el Bautismo como otra de las formas de regeneración y manifestación divina. En Cataluña, las tablas de Vallbona de les Monges (MNAC) profundizan claramente en estos nexos. Véase, para una perspectiva general, el conocido artículo de NILGEN, 


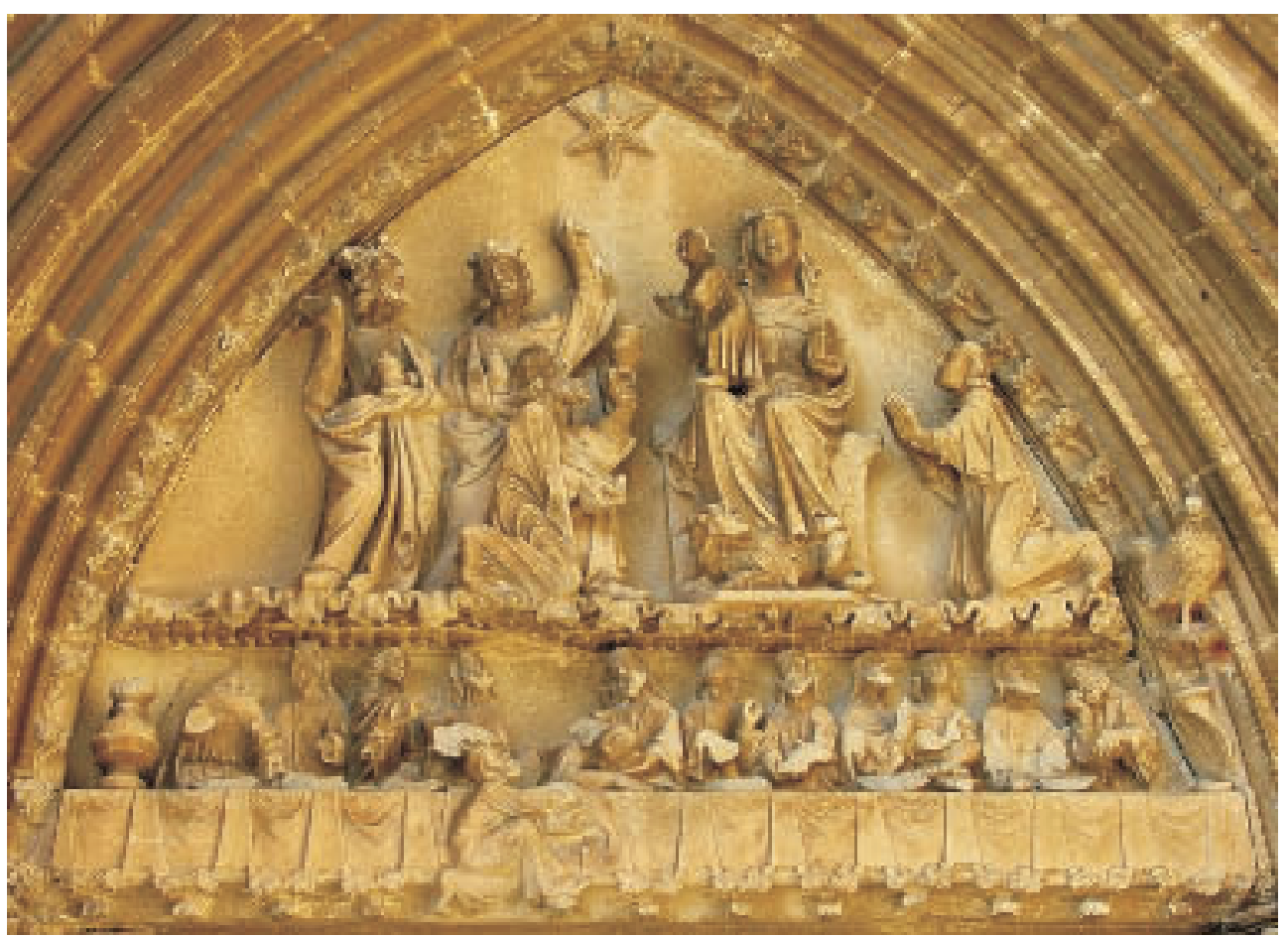

Fig. 9. Tímpano de la iglesia de Santa María de Ujué. Epifanía y Santa Cena, c. 1350-1360.

Morgan Library y el tímpano de Ujué difieren de Vezzolano porque los reyes y el donante se ubican en planos semánticos distintos como ocurría, aún más rotundamente, en el Libro de Horas de Juana de Navarra. En el tímpano esculpido se ha dado un paso más, pero las Horas de la reina de Navarra nos parecen válidas para interpretar lo que sucede en la escultura de Ujué. El grupo de la Virgen y el Niño responde a los reyes, pero esta comunicación no existe con el donante, al que nadie parece prestar atención, a diferencia de lo que hemos visto en Vezzolano (figs. 6 y 9). El orante, artificiosamente añadido a la escena bíblica del tímpano, se ubica arrodillado como el primer rey mago, en el lado opuesto al ocupado por éste y sus reales compañeros de viaje ${ }^{24}$.

La identificación del donante de Ujué no ha sido clarificada todavía de modo concluyente, aunque se han barajado diversas hipótesis de interés que afectan también a la cronología de esta escultura trecentista ${ }^{25}$. La identificación del donante con un rey no parece justificarse, ya que su indumentaria no corresponde con claridad a la de un monarca y no podemos esperar que su deseo, contradictorio a todas luces con el esfuerzo de hacerse representar en un lugar tan destacado, hubiese sido el de pasar desapercibido (fig. 10). Se ha hecho referencia a Carlos II, hijo

\footnotetext{
Ursula, "The Epiphany and the Eucaristist: On the Interpretation of Eucharistic Mofits in Mediaeval Epiphany Scenes", The Art Bulletin, XLIX, 1967, pp. 311-316.

${ }^{24}$ El Niño se sitúa en pie sobre la falda de la Madre, siguiendo un modelo de raíces septentrionales que también fue muy conocido en Italia. Se aplicó tanto a las Adoraciones de los magos como a las que hemos bautizado como Epifanías del donante. Lo curioso es que ahora el Niño parece caminar sobre la falda de María para aproximarse a los que le ofrecen presentes.

${ }^{25}$ Martínez de Aguirre, Javier, Arte y monarquia en Navarra 1328-1425, Madrid, 1987, pp. 93-94, nos remite a la tesis doctoral de Uranga, J. J., Ujué medieval, Pamplona, 1984.
} 
de Juana de Navarra y Felipe de Évreux, pero es más probable que fuese un hermano de éste, llamado Luis de Navarra o de Beaumont, lugarteniente del reino durante las ausencias de Carlos, quien promoviera la obra en Ujué y asumiera la representación en el tímpano, con lo cual se justificaría la ausencia de la corona sobre su cabeza, sin perder por ello el enlace directo con la realeza y la corte francesa, que nos devuelven a los planteamientos gráficos y artísticos paralelos que encontramos en el oracional de Juana de Navarra (fig. 7). Ello permitiría una datación de la obra esculpida a lo sumo en los años cincuenta del siglo XIV, unas fechas que se hallarían más acorde con el estilo flexible y todavía vagamente pucelliano de las esculturas, que no precisan ser llevadas a nuestro parecer hasta los años setenta ${ }^{26}$. Si nos remitimos a los alrededores del 1356 habrá que recordar que se trata de un período en que Carlos II estuvo prisionero en Francia y en el que su hermano Luis fundaría una capellanía en Ujué27.

Otra posibilidad de identificación se contempla en un artículo de Miquel Zuza Viniegra, que identifica al sujeto orante con el obispo de Calahorra Robert le Coq, personaje de compleja carrera que fue consejero del rey Carlos II entre 1362 y $1373^{28}$. A su parecer, las vestiduras del donante permiten considerar que se trata de una alta dignidad eclesiástica. Sin embargo, no deja de resultar extraño que tratándose de un obispo no haya utilizado ningún elemento distintivo del cargo episcopal. Por otro lado, el orante de la portada navarra no parece destacarse como clérigo tampoco en otros sentidos, hasta el punto de haberse podido ver en él al mismísimo rey, aunque sea sin la corona, aquélla que lo hubiese convertirlo en un sobresaliente cuarto rey mago. Un escrúpulo que otros reyes terrenales no tuvieron ${ }^{29}$.

La teoría de Miquel Zuza se afianza en segundo lugar en la presencia de un gallo, apostado en la arquivolta interna, que a su parecer puede entenderse como señal heráldica o emblema alusivo a la identidad de le Coq (fig. 10). No se trataría obviamente del escudo de le Coq, ya que en éste se incluyen tres gallos y no uno, como señala el mismo autor, sino de una versión libre alusiva a su nombre. Sin embargo, opino que esta alusión no se llega a concretar con suficiente claridad, de modo que puede ponerse en duda su verosimilitud. No hay que olvidar que otros autores ya interpretaron el gallo como motivo asociado a la escena inferior del tímpano, donde se despliega la Santa Cena. No estaría de más recordar aquí el texto de un himno cantado a la aurora e incluido en un antiguo Breviario $^{30}$. Debido al interés de su contenido, aplicado a nuestro tema, me parece oportuno reproducirlo nuevamente:

"Se levanta el lucero del día // y disipa las tinieblas del mundo, // con lo que la caterva de los malhechores // abandona el camino del crimen... // Levantémonos pues con diligencia; // el gallo despierta a los que duermen // e increpa a los somnolientos // el gallo acusa a los apóstatas // con el canto del gallo vuelve la esperanza // los enfermos recobran la salud // se esconde el puñal de los asesinos // y los caídos recobran la fe".

${ }^{26}$ La incidencia de la obra de Jean Pucelle y de sus seguidores en la Península es un tema muy interesante que nos descubre situaciones extraordinarias como la del maestro de vidrieras normando Guillem de Letumgard, activo en Cataluña. Vid. Alcoy, Rosa, "Guillem de Letumgard y el reflejo de Pucelle en Cataluña" Patrimonio artístico de Galicia y otros estudios. Homenaje al profesor Dr. Serafin Moralejo Álvarez, 3 vols., vol. I, Santiago de Compostela, 2004, pp. 1-20.

27 Utilizamos los datos de Uranga, J. J., Ujué medieval..., reseñados por Martínez de Aguirre, J., Arte y monarquía..., p. 302.

28 ZuZa Viniegra, Miquel, "Sobre una posible identificación del donante en la portada de Ujué”, Príncipe de Viana, n. 226, vol. 63, 2002, pp. 327-335. Agradezco la indicación sobre la existencia de este artículo al profesor Gonzalo Borrás Gualis.

29 Trato de todo ello en Alcoy, Rosa, Anticipaciones del Paraíso..., en prensa. La versión original de este estudio en proceso de publicación, organizada en tres volúmenes, incluye una recopilación de fuentes textuales.

${ }^{30}$ El escrito corresponde a la primera hora del oficio del coro de la Iglesia (Laudes) y se transcribe aquí a partir de Sebastián López, Santiago, Iconografía Medieval, San Sebastián, 1988, p. 190, autor que agradece la referencia al profesor A. Rodríguez Ceballos. 


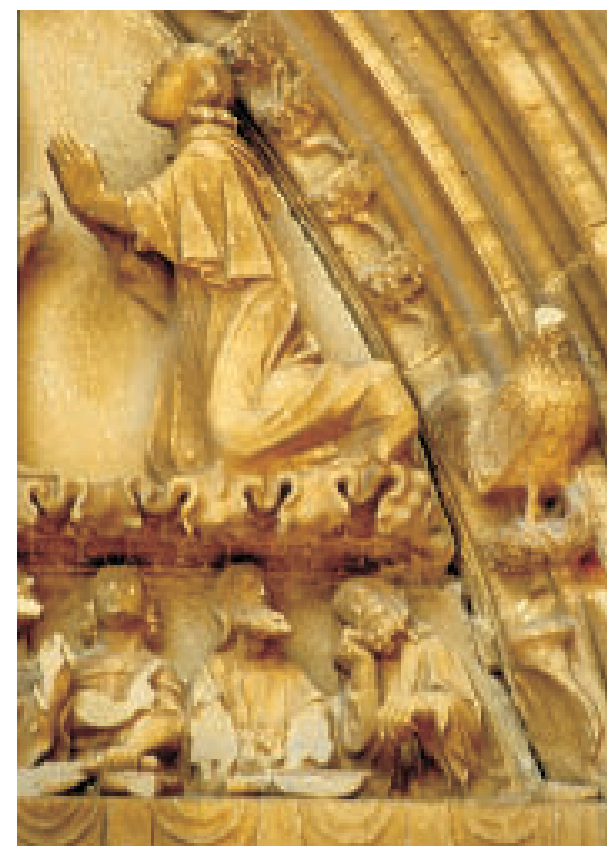

Fig. 10. Donante y gallo. Detalle del tímpano de la iglesia de Santa María de Ujué. c. 1350-1360.

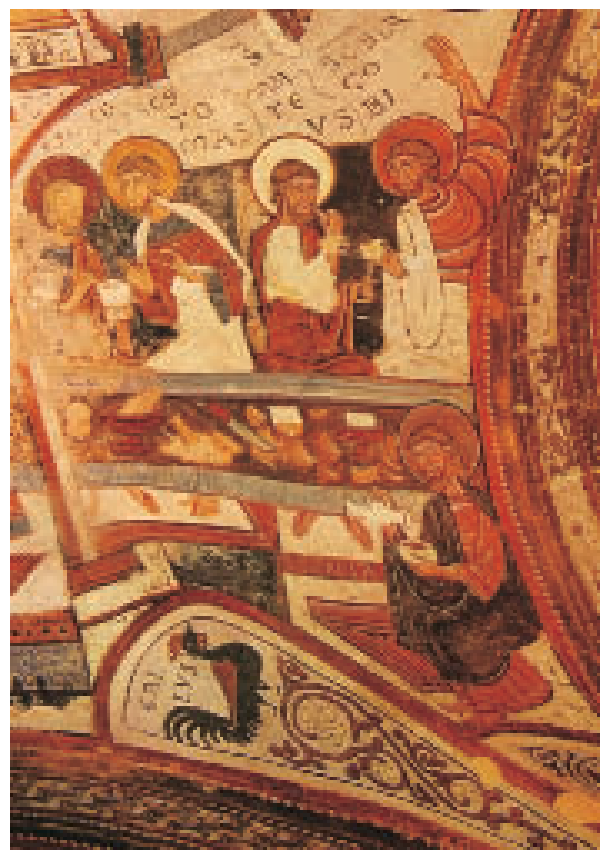

Fig. 11. Detalle del gallo y de la Santa Cena de las pinturas murales de San Isidoro de León.

Como indicara Santiago Sebastián, el gallo puede alcanzar una significación espiritual que evoca la salvación a través de la muerte de Cristo, al relacionar la luz matutina y la luz espiritual. En Ujué la relación puede establecerse al mismo tiempo con la Epifanía y con la Santa Cena sin descuidar la idea de una llamada a todos aquellos que deben despertar de su letargo o sueño y dirigirse a adorar a Jesús como lo hacen los tres reyes y el donante emplazados ante la Virgen y el Niño. El gallo rompe con el letargo que ya preocupaba en el salterio. La evocación hace pensar en algunos salmos y en los versos de los mismos utilizados durante la celebración de la festividad epifánica. Una idea semejante referida al gallo se refleja en la obra de don Juan Manuel, "Fabla en como Julio dixo al Infante qual fue la razón segúnt la cual, que el semejaba por que Nuestro Señor nasçiera a la media noche quantdo cantaba el Gallo" "11. El gallo señala el abandono de las tinieblas que llega con el nacimiento de Cristo y despierta al hombre de su sueño, aquel que simboliza el pecado, y lo incita a seguir por el camino de la salvación. De este modo, en Ujué es factible hacer referencia a dos tipos distintos de traiciones, la insalvable de Judas y la de un san Pedro redimido. Ambas preludiarían el desenlace pasional sin deslucir el momento gozoso desarrollado en lo más alto y desdoblado como tema epifánico y neo-epifánico que se conmemora en lo eucarístico. No me parece insignificante la proximidad del gallo a la Santa Cena, por citar sólo alguna de las tradiciones que arraigan en la península, en las pinturas románicas del Panteón Real de San Isidoro de León, al margen, claro está, de cualquier interpretación heráldica (fig. 11) 32 .

${ }^{31}$ Manuel, Juan, Libro de los estados, edición según el manuscrito de la Biblioteca Nacional por José M. ${ }^{\text {a Castro }}$ Calvo, Departamento de Literatura española de la Universidad de Barcelona, Barcelona, 1968, p. 202.

32 Puede verse en Viñayo GonzÁlez, Antonio, Pintura románica. Panteón Real de San Isidoro-León, León, 1979, figs. 18 y 22 . 
Con todo, y aunque la seguridad absoluta no ha existido en cuanto al donante, y quizá tampoco en otros puntos, el interesante programa diseñado en la portada conduce al ámbito europeo y al entorno internacional en que se movieron Carlos II y su hermano Luis. Un camino que prefiguran otras importantes creaciones navarras de la primera mitad del siglo, es decir, de los tiempos de oro en que el reino fue gobernado por Juana de Navarra y Felipe de Évreux, los padres del rey Carlos, de Luis y también de María de Navarra. Esta última se convertiría también en reina al casarse con Pedro III (IV) de Cataluña y Aragón ${ }^{33}$. Todo ello dibuja un marco artístico coherente que no puede ser obviado al analizar la obra y que tampoco puede desatenderse llegado el momento de fijar su cronología ${ }^{34}$.

\section{De la tierra al Cielo}

En otras ocasiones el comitente se añadió a la combinatoria del cortejo real para encontrar el modo de adherirse a los magos, que lo vincula a la escenografía y al movimiento que caracteriza el episodio. Ello permite superar aquellas situaciones que lo dejaban justo en los márgenes de la escena, como figura expectante o disociada ${ }^{35}$. En Sant'Eustorgio de Milán, uno de los relieves frontales del sarcófago de Gaspare Visconti, atribuido al Maestro bavarese del 1427, refleja cómo uno de los magos acompaña al donante, no impropiamente llamado Gaspar, hacia la Virgen (fig. 12). Por consiguiente, vemos como el personaje asociado a su patrón se vincula a la Epifanía histórica ${ }^{36}$. El sujeto se integra así en la acción, de tal manera que los reyes acaban por remplazar a los ángeles y los santos, aquellos que ampararon normalmente al difunto en su progresión hacia la Virgen y hacia el Cielo. En este caso los santos patronos o "procuradors", como los llamara Ramon Llull, comparecen en los flancos del sarcófago: "A membrar nos cové la glòria de paraís, per ço que la desirem; membrem les infernals penas, perço que les temam (...). Cascuna de nosaltres remembre alcun sant special qui sia son procurador en la cort celestial (... $)^{37}$. La secuencia narrativa envuelve el tema votivo y expresa, con más fuerza que en otros casos, la conciencia sobre la relación, o fondo común, que asocia ambos temas. La afortunada coincidencia del nombre de Gaspar Visconti con el de uno de los magos posibilita esta ingeniosa elección que, al mismo tiempo, singulariza su tumba.

A un maestro lombardo, aproximado a la escuela o entorno de Micchelino di Besozo y Stefano da Zevio, puede referirse un bello estudio de la Epifanía que conserva la colección Albertina (Viena) (fig. 13) ${ }^{38}$. La Adoración de los magos se encuentra al pie del folio membranáceo, trabajado con estilo de plata, en que comparecen también otras figuras antropomorfas y zoomórficas

${ }^{33}$ No son éstos los únicos hijos de Juana de Navarra y Felipe de Évreux, pero nos interesa destacarlos por encima de otros en función de su vinculación a los reinos peninsulares. Hay que recordar aquí el Libro de Horas asociado a la reina María, mujer del Ceremonioso, obra conservada en Venecia que, pese a su marcado carácter italianizante, recurre a significativos modelos septentrionales.

34 Vid. LacARra DucaY, María Carmen, Aportación al estudio de la pintura mural gótica en Navarra, Diputación Foral de Navarra, Instituto Príncipe de Viana, Pamplona, 1974.

35 Para el contexto gallego, ya recordado brevemente, remito a CAAMAÑo MARTíneZ, J. M., "Seis tímpanos compostelanos de la adoración de los Reyes", Archivo Español de Arte y Arqueología, XXXI, 1958, pp. 331-338.

36 CAvazzini, Laura, Il Crepuscolo della Scultura medievale in Lombardia, Leo S. Olschki ed., Città di Castello, 2004, fig. 132, lo sitúa como maestro lombardo del tercer decenio del Quattrocento. Un caso menos claro es el que ofrecen los murales de San Donato in Polverosa de Florencia, vinculados a Cenni di Francesco. Vid. Miklos BosKoviTs, Pittura fiorentina alla vigilia del Rinascimento, 1370-1400, Florencia, 1974, fig. 237. Las dos pequeñísimas imágenes de las donantes comentan el gran acontecimiento sin que podamos constatar su participación en el mismo.

37 Llull, Ramon, Llibre d'Evast e Blanquerna, vol. I, a cura de Mn. Salvador Galmés, ed. Barcino, Barcelona, 1935, p. 193.

${ }^{38}$ El dibujo fue publicado por ToEsCA, P., La pittura e la miniatura nella..., fig. 353. 


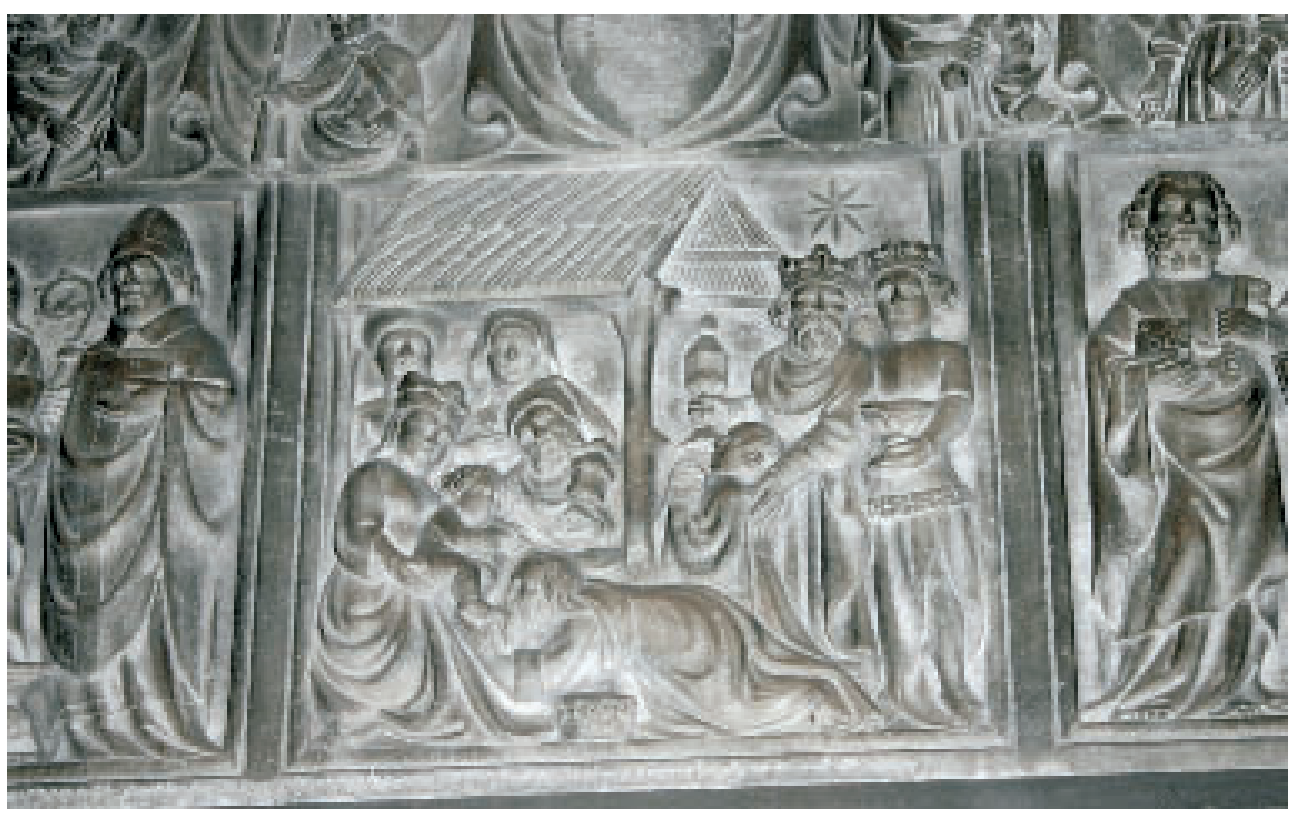

Fig. 12. Relieve del sarcófago de Gaspare Visconti, Epifanía, Milán, Sant'Eustorgio, c. 1427.

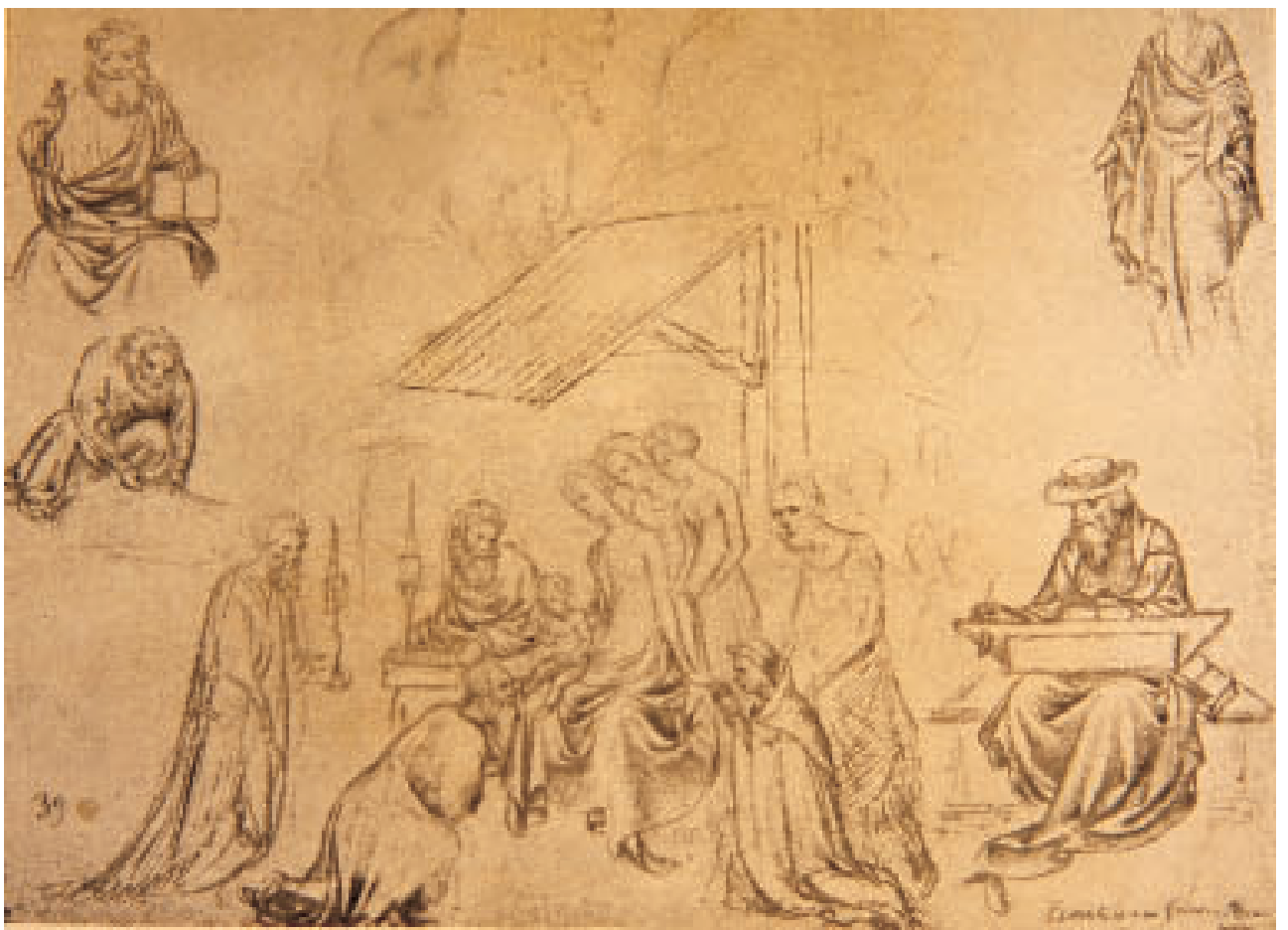

Fig. 13. Maestro lombardo. Detalle de un folio con el dibujo de la Epifanía y otros esbozos. Viena. Albertina, c. 1400. 
(una Virgen con el Niño, santos, profetas y hasta un leopardo). Todo ello y también la Epifanía nos recuerda el conocido peso de estos modelos del norte italiano, vinculados a centros lombardos, sobre el arte de los Limbourg y, más concretamente, en las Trés Riches Heures del Duque de Berry. La calidad y delicadeza del trazo de este dibujo permiten ver la intención de un maestro de primer orden, que agrega el donante a la Adoración de los magos, posiblemente un clérigo, que se arrodilla al lado derecho al igual que lo hace por el izquierdo el primero de los reyes ${ }^{39}$. El personaje es acompañado hasta la Virgen por una santa. De hecho, el grupo de las mujeres que asisten a María destaca ya en el dibujo de la Albertina, para crecer todavía más en la Epifanía pintada por los Limbourg para el duque de Berry.

La Epifanía de los reyes y la del donante configuran dos tipos diferentes de Epifanía que, sin embargo, admiten un desarrollo semejante, coincidiendo de forma ostensible en uno de los planos de la figuración, aquel que lleva a subordinar uno o más personajes a las imágenes de la Virgen y el Niño. La Virgen se convierte en apoyo de la divinidad que se ofrece en teofanía. Ahora bien, el carácter genérico y simbólico adquirido paso tras paso por los reyes de Oriente, sea como representantes de las distintas civilizaciones o universos que reconocen la verdad cristiana, se concreta y se limita al mismo tiempo cuando sus imágenes son suplantadas por la del responsable del encargo, sea acompañado o no por sus familiares y allegados, en los márgenes de la obra votiva o del ciclo sepulcral.

La proximidad de la Epifanía a la representación del donante ante la Virgen y el Niño refuerza asimismo las ideas ya expuestas en obras que se prodigan sobre todo a lo largo del siglo XV. El retablo del monasterio de la Domus Dei de Miralles (MNAC y colección Mateu de Peralada), que se documenta de forma indirecta como obra de Antoine Lonhy ${ }^{40}$, en función de la relación de este maestro con el bordador Antoni Sadurní ${ }^{41}$, se adhiere al planteamiento iconográfico que he descrito al avecinar el tema de los magos al de un donante que reza ante la Virgen, madre y reina del Cielo. El tamaño del grupo sagrado se agranda para cumplir las expectativas de la tabla central, el Niño se halla desnudo y María coronada, pero ello no desmiente la conexión entre ambos episodios. Una solución bastante próxima la brinda el códice de Péronet Lamy, primer Maestro

\footnotetext{
${ }^{39}$ La relación entre la corte de Jean de Berry y la Lombardía tiene un aliado en la figura de Alcherius, conocido tratadista sobre el arte de la pintura, que fue agente del duque y que viajó por diversas zonas de Italia, Francia e Inglaterra para conocer mejor las técnicas y recetas de los mejores talleres del momento. En 1382 Alcherio se encontraba en Milán, ciudad desde la que viaja a París, llevando consigo recetas para la fabricación de tintas. En 1398 se encuentra en París en contacto con Jacques Coene y otros miniaturistas. De retorno a Milán, donde se halla de nuevo a finales de la primera década del siglo $\mathrm{XV}$, sigue interesado por los recetarios y las técnicas, manteniendo contactos con maestros diversos, entre los cuales se encuentran Juan de Módena y Michelino de Besozzo. En 1410 vuelve a París y redacta el De coloribus diversis modis tractatus y el De diversis coloribus, recogidos más tarde (1431) por Jean Le Begue en un manuscrito misceláneo (BNF, ms. lat. 6741). Alcherio ejemplariza los enlaces entre estos centros italianos y el ámbito septentrional en que debieron formarse los Limbourg.

40 Sterling, Charles, "Études Savoyardes II. Le Maître de la Trinité de Turin”, L'Oeil, novembre de 1972; AvriL, François, "Le Maitre des Heures de Saluces: Antoine de Lonhy", Revue de l'Art, n. ${ }^{\circ} 85$, 1989, pp. 9-34. Romano, Giovanni, "Sur Antoine de Lonhy en Piémont", Revue de l'Art, n. ${ }^{\circ} 85,1989$, pp. 35-44.

${ }^{41}$ El 1462 Lonhy realizaba cartones y modelos para este bordador que recibiría algunas cantidades que se adeudaban al primero, pintor y maestro de vidrieras, por la realización del retablo de Miralles. La factura y estado de conservación de la obra han creado dudas sobre la conveniencia de esta atribución a Lonhy, un maestro que también había ejecutado la magnífica vidriera del rosetón de la Coronación de la Virgen en la fachada principal de Santa María del Mar (Barcelona). Para la documentación referida al retablo: SANPERE I MiQUEL, Salvador; Los cuatrocentistas catalanes, I, Barcelona, 1906, p. 312 y Madurell Marimón, Josep M., "Antoni Sadurní", El Arte en la comarca Alta de Urgel, Anales y Boletín de los Museos de Arte de Barcelona, 1946, pp. 88-97, pp. 90-92, notas, 239-241. Vid. el volumen dedicado a Santa María del Mar del Corpus Vitrearum Medii Aevi, Catalunya-1 y Alcoy, R., "La evolución de la vidriera en la Cataluña medieval" y "Las vidrieras de Santa María del Mar", en BARRAL, Xavier (ed.), Vidrieras Medievales en Europa, Lunwerg ed., Barcelona, 2003, pp. 168-209.
} 
de las Horas de Luís de Saboya, en conexión con la obra de Lonhy ${ }^{42}$, al mostrar a la donante ante el Niño desnudo y la Virgen entronizada con un pequeño ramo de flores, que también se ha puesto en sus manos en el retablo de la Domus Dei de Miralles ${ }^{43}$. En la miniatura la versión se encuentra lateralizada y la donante es presentada por dos santos con hábitos oscuros, pero el enlace icónico entre la tabla de Barcelona y el libro conservado en Londres es interesante.

El famoso Díptico Wilton de Ricardo II de Inglaterra (National Gallery de Londres) jugó ya mucho antes con el recuerdo de la Epifanía, aunque en un sentido muy peculiar (fig. 14) ${ }^{44}$. En el ala izquierda el monarca aparece acompañado por sus santos patrones: san Eduardo el confesor, san Edmundo y san Juan Bautista. Son tres, por tanto, las figuras que llevan coronas, Eduardo, Edmundo y el rey inglés, y que deslindan un grupo coherente que se asemeja mucho al formado por los tres reyes magos. Sólo difiere la figura del Precursor que, con el Cordero en el regazo, sitúa una mano sobre la espalda de Ricardo II arrodillado ${ }^{45}$. La obra, considerada hoy por diversos autores de hacia 1395, plantea la Epifanía del rey como una nueva Epifanía que nos persuade sobre un nexo largamente cultivado y voluntariamente inclinado a aproximar a los reyes de las diversas naciones europeas a los reyes de Oriente. En esta ocasión, la pintura no se limita a usurpar el lugar de los sabios coronados para emplazar al donante, aprendiz de mago, ante una singular Virgen en pie, rodeada de un sofisticado coro angélico. Ricardo II, acompañado de dos santos reyes, nos brinda una imagen sabedora de la ambigüedad formal que invade la figuración para retrotraer al espectador sobre los contenidos y pensamientos más celebrados y populares del tema epifánico.

No es casual que Ricardo II, nacido en Burdeos el día 6 de enero, coincidiendo con la fiesta de la Epifanía y el día del Bautismo, se relacione muy estrechamente con el tema de los magos $^{46}$. La Virgen celestial brinda al rey inglés una calurosa bienvenida que ha sido interpretada como verdadera recepción en el Cielo. Wormald asentó una datación tardía del Díptico Wilton, posterior a la muerte del rey en 1400, para explicar la pintura como un singular traspaso que lleva al rey de la Tierra al Cielo ${ }^{47}$. Utiliza para demostrar su tesis otros ejemplos de presentación celestial. Sin embargo, y atendiendo a todo lo visto y analizado, queda claro que este tipo de representaciones pudieron tener un alcance múltiple, que no hacía obligado que el donante hubiese muerto. La datación temprana del Díptico Wilton se justifica por razones vinculadas con la imagen del rey, con su buscada juventud y con unos precedentes que se sitúan en miniaturas francesas de hacia $1390^{48}$, pero que también pueden ser anteriores ${ }^{49}$. En definitiva, y al igual

${ }^{42}$ London, British Library, ms. Add.27697, fol. 19. Vid. Les Arts sous Charles VI. Paris 1400, Paris, 2004.

${ }^{43}$ El motivo floral se prodiga ya en la tradición trecentista. Lo vemos en una interesante imagen de la reina ante la Virgen y el Niño en el fol. 245 de un códice de los Milagros de nuestra Señora conservado en París (Paris, BNF, ms. lat. 24541), pero podrían citarse ejemplos para la escultura.

${ }^{44}$ Lo tenía ya en cuenta en AlCOY, R., "Acerca de algunas epifanías extemporáneas..."

45 Wormald, Francis, "The Wilton Diptych", Journal of the Warburg and Courtauld Institutes, XVII, 1954, pp. 191-203, Gordon, Dillian (ed), The Wilton Diptych, London, 1993.

46 También lo habían hecho otros muchos reyes, que festejaban el acontecimiento con presentes que reproducían de algún modo las antiguas ofrendas de los sabios de Oriente. El hecho es remarcado por D. Gordon que, al comentar el Díptico Wilton, coincide con algunos de las ideas que apunté en mi trabajo de 1987 sobre las Epifanías extemporáneas o Epifanías del donante. En aquella ocasión ya se estudiaba la obra inglesa en clave epifánica, asociándola al recurrente tema de imitación de los magos que incumbe a muchos otros contextos.

47 "The scene shows an occasion which is no longer of this word and must in fact represent the King's reception in Heaven". Vid. Wormald, Francis, "The Wilton Diptych...", p. 201.

${ }^{48}$ Gordon, D. (ed.), The Wilton Diptych... Previamente había estudiado la obra SANDLER, L. F., "The Wilton Diptych and Images of devotion in illuminated manuscripts", Richard II, the Regal image and Wilton Diptych, London, 1977, pp. 137-54.

${ }^{49}$ La representación de la Epifanía en dos espacios separados, el que corresponde a los reyes y el propio de la Virgen y el Niño, es visible en obras de diverso tipo. Entre ellas no falta algún que otro códice donde se utilizan el 

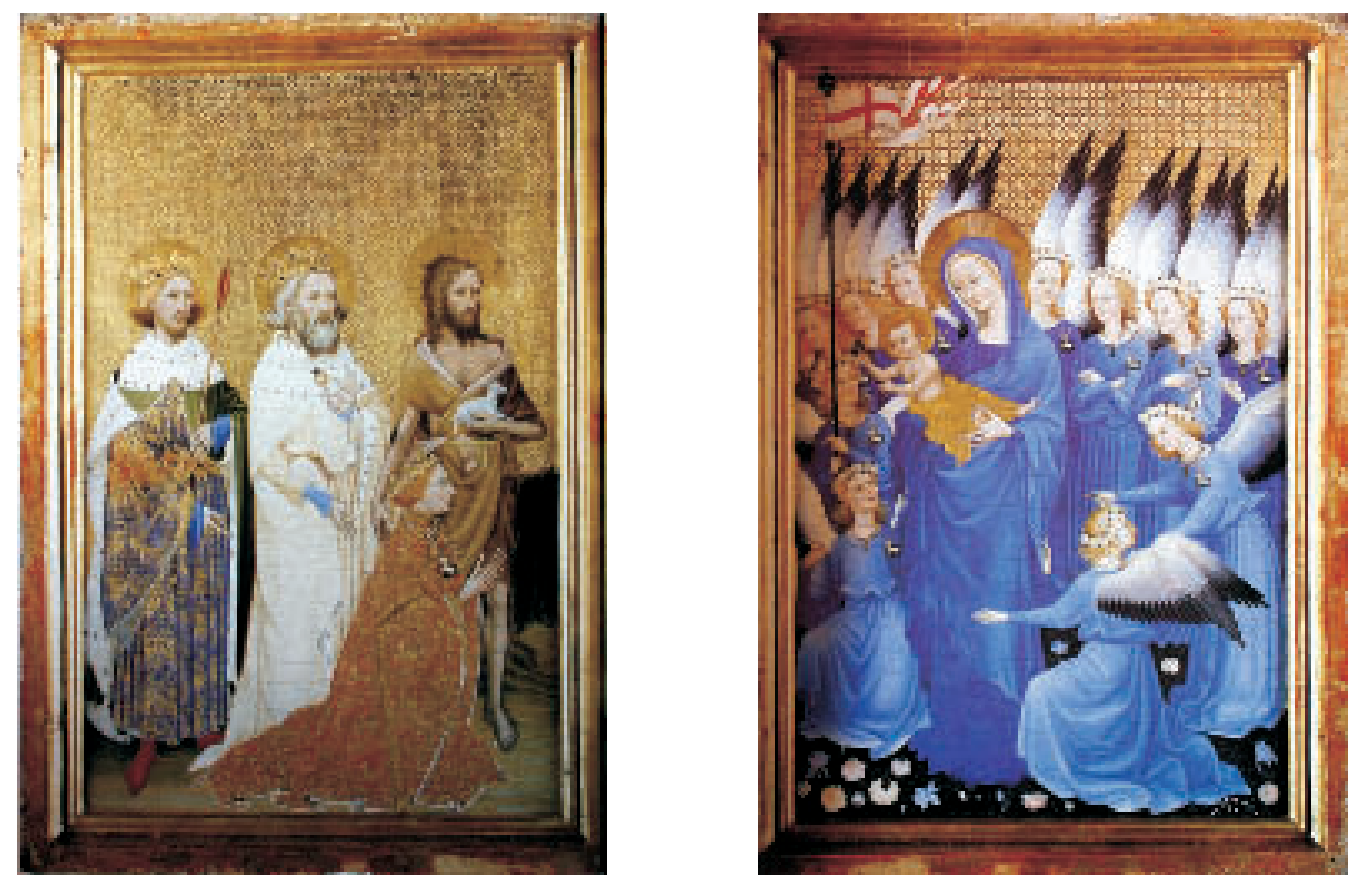

Fig. 14. Díptico Wilton. Londres, National Gallery, c. 1395.

que en otros muchos casos, incluso en algunos referidos a personajes ciertamente difuntos, la escena adquiere un valor anticipatorio que redunda en una posibilidad sospechada, en un evento previsto, más que en la descripción de un hecho que pueda considerarse consumado. Los fondos de oro, visiblemente caracterizados por el distinto trabajo de los punzones que se ha realizado en los dos compartimentos, señalan una distancia que impone también la separación física real del marco y que se refleja asimismo en la distinción de los suelos: el suelo rocoso donde se sitúa el donante y el suelo vegetal poblado de flores en que evolucionan la Virgen, el Niño, y los ángeles, singularmente convertidos al equipo del donante, el del White Hart o Ciervo Blanco. Esta visión posibilista de la escena tiene sentido tanto antes como después de la muerte del monarca ${ }^{50}$. Se

verso y el anverso de dos folios sucesivos. Este sería el caso del Libro de Horas de María de Navarra, ilustrado en el taller de los Bassa.

${ }^{50}$ El tema de la datación del díptico es mucho más complejo de lo que podría parecer a primera instancia, ya que los santos-reyes que acompañan a Ricardo II son los últimos reyes de sus respectivas dinastías y san Juan Bautista, el último de los profetas. Con Ricardo II, asesinado en 1400 sin descendencia, se interrumpe su línea directa, lo que habría podido propiciar cierto paralelismo con los santos mencionados. Como es sabido, le sucederá en el trono su primo hermano Enrique de Lancaster, convertido en Enrique IV. Panofsky consideraba el estilo de la obra como versión inglesa a partir de modelos flamencos y franceses y la ubicaba hacia 1415 (PANOFSKY, Edwin, Les primitifs flamands, París, 1992 (1971), fig. 202, p. 230), dando la razón a los que consideraron el Díptico como obra conmemorativa que glorificaba el acceso del rey al Cielo. A su parecer el comitente debió de ser Enrique V quien, después de acceder al trono en 1413, transfirió el cuerpo de Ricardo II a la abadía de Westminster. Con todo, la opción de representar bien vivo al joven rey, orante ante la Virgen y el Niño, sigue una tradición activa, que puede ser vinculada o quedar al margen de un contexto funerario preciso. Una realización después de su muerte no encaja a la perfección con el valor epifánico y festivo, con el deseo de identificación con los magos, más que de imitación de los magos, que se pronuncia en esta pintura relacionada con los cultos hagiográficos de la monarquía y de la abadía de Westminster. 
ha pensado en un encargo realizado por su mujer Ana de Bohemia, fallecida en 1394, o por su segunda esposa, la joven Isabel de Francia, hija de Carlos VI. El remarcable valor personalizado de la obra y su inadecuada adaptación como memorial postmortem de un rey asesinado llevan a descartar estos tanteos ${ }^{51}$. Se trata, con todo, de un terreno muy resbaladizo, ya que la adecuación de las obras a sus distintas funciones admite muy diversos planos de interpretación, y lo que pudiera no tener mucho sentido como exaltación generalizada puede preservar su atractivo en un círculo más íntimo de allegados que se predisponen a recordar al monarca con toda su belleza y sofisticado fasto ${ }^{52}$.

Aún siendo uno de los ejemplos más claros, Vezzolano no es, como ya se ha sido visto, el primer ejemplo que aparece en la larga serie de Epifanías del donante del periodo medieval (fig. 6). Con todo, es uno de los singulares casos en que se hace explícita una idea que normalmente quedó sumergida, sobrentendida o encubierta. Por consiguiente, los murales del siglo XIV no nos indican el inicio de nada, pero junto a otros ejemplos reseñados nos indican la trascendencia general del tema epifánico, incluso al margen de la conciencia, mayor o menor, que sobre estos contenidos pudieran tener realmente algunos maestros o ejecutores de obras. En cualquier caso, la Epifanía con el donante sita en el claustro de Vezzolano junto al tema de los Tres vivos y los tres muertos y una imagen de la Maiestas Domini rodeada por el tetramorfos ${ }^{53}$, tuvo interesantes raíces en algunos centros de Italia que permiten analizar casos muy anteriores de explotación de esta idea en una tradición extendida por toda la Europa occidental y de la que el mundo hispánico no quedó al margen.

El número de neo-epifanías es tan grande que, ya al inicio de un primer trabajo sobre el tema, renunciaba a establecer un catálogo exhaustivo de estas escenas que muestran al donante, ya fallecido o aún en vida, ante María y el Niño. El valor de estas imágenes, concebidas y sancionadas para prescribir la llegada del ser humano a la Jerusalén celestial, anticipan la llegada a un Paraíso que se prepara desde la tierra y que todavía no ha sido realmente alcanzado ${ }^{54}$. En fechas recientes he retomado el tema con voluntad de matizar, ampliar y reordenar las ideas anteriormente expuestas. Aunque el catálogo exhaustivo de las "Epifanías del donante" continúa siendo un objetivo aplazado, o mejor dicho, un objetivo dinámico, me ha sido posible abordar un

${ }^{51}$ No se olvide que Ricardo encarga su tumba en 1395, donde comparece junto a su primera esposa Ana de Bohemia, fallecida poco antes. En ella puede leerse una inscripción que demanda la salvación para el devoto Ricardo que goza del favor del Bautista: "O clemens Christe - cum devotus fuit iste; Votis Baptiste salves quem pretulit iste". Vid. Gordon, D. (ed), The Wilton Diptych., p. 61. Sobre la vinculación entre la Epifanía y el Bautismo de Cristo basta con remitirse a la coincidencia de días, a las celebraciones litúrgicas del día de la Epifanía o a las alusiones sobre este particular en textos tan divulgados como la Leyenda Dorada.

52 Una situación comparable, aunque distinta, llevaría, atendiendo a una hipótesis en la que todavía trabajo, a la reina viuda Violant de Bar, prima hermana de Carlos VI y tía-abuela de Isabel de Francia, a encargar al pintor catalán Joan Mates un retablo dedicado a los santos Juanes, probablemente en memoria de su esposo, el difunto rey, Juan II. Apuntaba ya algo en este sentido en ALCOY, Rosa y Miret, Montserat, Joan Mates, pintor del gòtic internacional, Sabadell, 1998.

${ }^{53}$ El tema de los Tres vivos y los tres muertos se aposentó en la Europa gótica a modo de parábola visual ejemplificadora, que enfrentaba al ser humano a la caducidad de su vida presente. En combinación con el tema de la Epifanía, el encuentro con la muerte subraya la dimensión funeraria del primer tema pero no lo hace a costa de su acepción prospectiva. Vid. SetTis Frugoni, Chiara, Il tema dell'Incontro dei tre vivi e dei tre morti nella tradizione medioevale italiana, Atti della Academia Nazionale dei Lincei. Memorie Classe di Scienze morali, storiche e filologiche, Roma, 1967.

${ }^{54}$ La única versión conservada de las llamadas Homilías de Organyà, emplazadas generalmente a fines del siglo XII o inicios del siglo XIII, se abre con unas lacónicas palabras que según se ha establecido corresponden al final de una Homilía, que no ha sido posible identificar. Pese a lo escueto de la cita, cada una de estas palabras es significativa para el contexto que intentamos reconstruir: "[1v.]... paradis e en aquela glòria siam portads/... davant lo fil de la Verge. Quod $i<p s e>/<$ prestare dignetur>”, tomada de Homilies d'Organyà, edició facsímil del manuscrit núm. 289 de la Biblioteca de Catalunya, introducción, versión adaptada al catalán moderno y glosario a cargo de Jordi Bruguera, edición crítica y anotada de Joan Coromines, Barcelona, 1989, p. 45. 
número mucho mayor de creaciones que permiten desarrollar tratamientos monográficos sobre una sustancial cuestión de fondo, sin olvidar la especificidad y singular problemática de cada una de las obras analizadas. Las Epifanías con donantes merecían situarse en el centro de estos análisis y éste ha sido el objetivo principal que he reseguido hasta aquí, sin olvidar que el tema de la Adoración de los reyes magos supera en interés la que fue su más habitual mise en scène para ofrecer sus recursos y valores a un asunto que, visto como potencial Epifanía al donante, se convirtió en su principal esqueje iconográfico. La predisposición al uso de las analogías y los maridajes icónicos característicos de la etapa medieval favorecerían, sin duda, un discurso abierto que, preferentemente en contextos funerarios, sacaba partido a algunos de los contenidos fundamentales del tema de los magos. La insinuación sobre el arribo del ser humano a la Ciudad eterna, más que una insinuación en obras como el Díptico Wilton, tomaría prestados contenidos que ya se encontraban en la Epifanía y que hacían de los magos maestros, modelos o paradigmas a seguir por los muchos novicios e iniciados, atentos al discurso de la Iglesia cristiana. Se multiplicaron así las ocasiones que matizaban algunos de los valores esenciales del encuadre inaugural para enfocar mejor la cuestión sobre un vivo o un difunto, que cambia con cada nuevo caso, e impone algo de su personalidad al nuevo tema.

La difusión de estos motivos dentro de la geografía europea debe de obedecer a ciertas leyes que no son fáciles de aislar, aunque se puedan delimitar diversas responsabilidades. Una de las

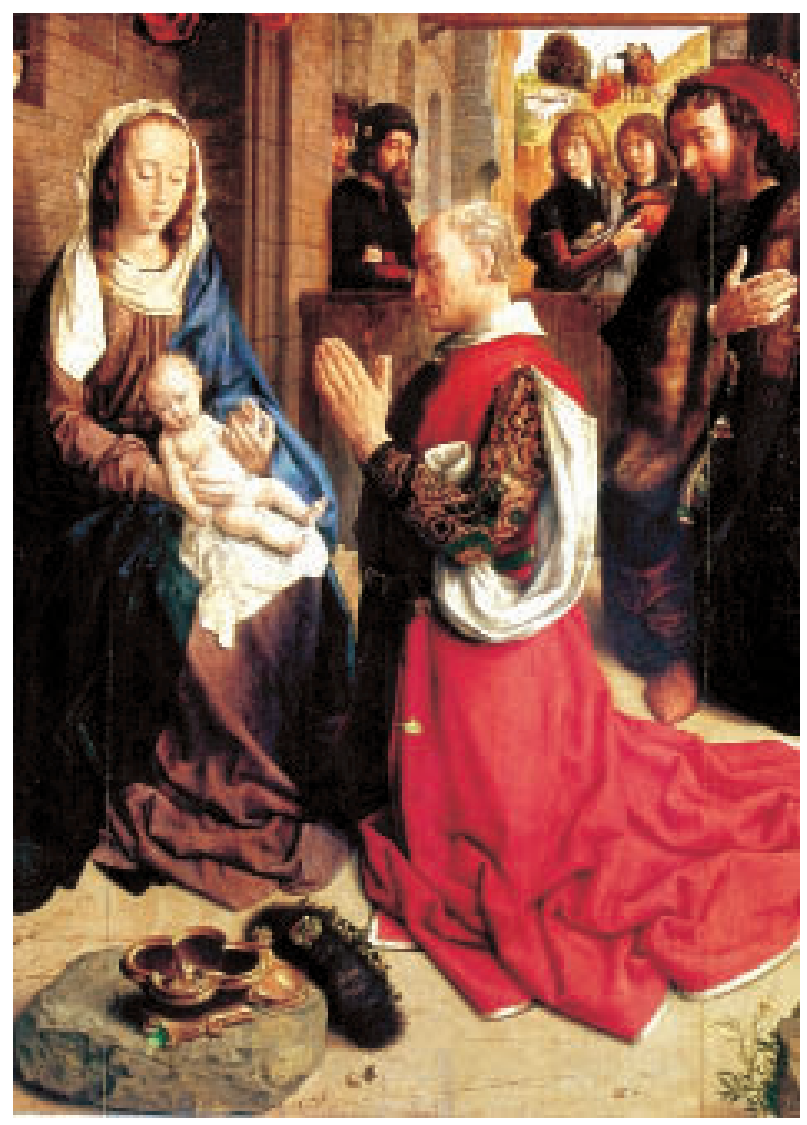

Fig. 15. Hugo Van der Goes, detalle del retablo de Monforte, Berlín-Dahlem, Gemäldegalerie, c. 1470-1472. 


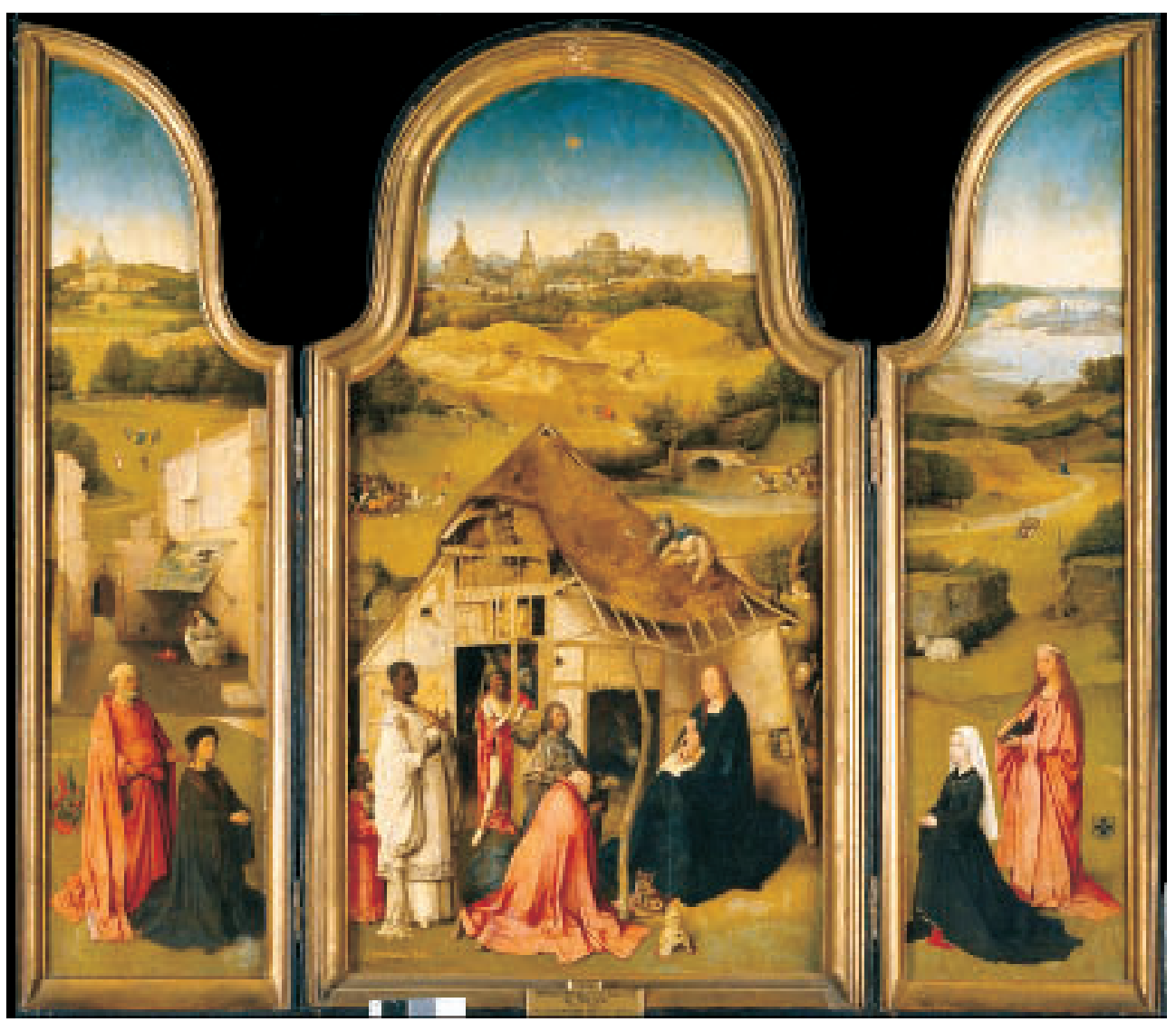

Fig. 16. El Bosco, Tríptico de los reyes Magos, abierto, Madrid, Museo Nacional del Prado, c. 1510.

razones de la dificultad es la misma proliferación de este tipo de composiciones y la utilización simultánea del icono de la Virgen y el Niño. Esta imagen beneficia múltiples soluciones alternativas y desviaciones que deben valorarse adecuadamente. En cualquier caso, la intensidad o frecuencia de las representaciones que pueden adscribirse al catálogo de las neo-epifanías no es homogénea y los modelos utilizados en unas y otras zonas no son tampoco idénticos. En el marco italiano las obras dignas de atención son muy numerosas y desbrozan un camino seguro que no concluye al finalizar la llamada Edad Media.

La cuestión que nos ocupa se sostiene sobre las migraciones temáticas y de sentido que con frecuencia caracterizan el quehacer artístico. Los "temas de encuadre" que definiera Bialostocki y que, según él mismo expuso, pueden mostrar "un claro simbolismo espiritual" 55 , tienen algo que ver con los trasvases de contenidos abordados a partir de las ramificaciones de la Epifanía histórica. En el caso específico que ha sido analizado, la búsqueda del tema de encuadre permite ahondar en el sentido de unas imágenes votivas que confluyen con el sentido, las funciones y los valores atribuidos a la Adoración de los reyes magos, a su escenificación y a su liturgia. Quedan prudencialmente al margen de este artículo algunos de estos desarrollos y, asimismo, el tema del

55 Bialostocki, Jan, Estilo e iconografia. Contribución a una ciencia de las artes, Barcelona, 1973, p. 114. 


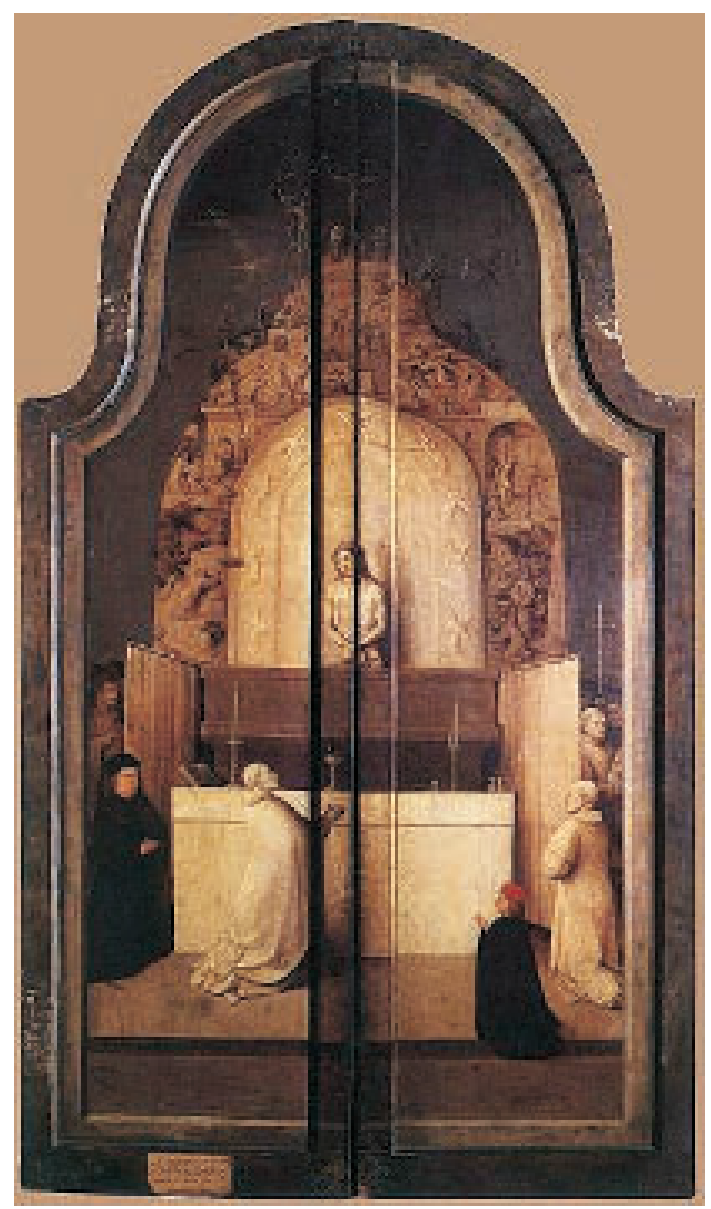

Fig. 17. El Bosco, Tríptico de los reyes Magos, cerrado,Madrid, Museo Nacional del Prado.

donante en las Epifanías del siglo XV, tanto en el marco de la pintura flamenca y septentrional como en la Italia renaciente ${ }^{56}$. El donante puede suplantar al rey-mago sin desplazarlo definitivamente del lugar que éste ocupa. Este atrevimiento final que intenta identificar a los donantes en los mismos magos, a través de los retratos de los primeros que se imponen a los cuerpos de los segundos en escenas concebidas como escenas históricas, comporta paralelamente la traslación del gesto y la actitud de los antiguos donantes a los nuevos magos. Así puede establecerse para alguna de las obras de Fernando Gallego y en la conocida Epifanía de Monforte de Hugo van der Goes (Staatliche Museen de Berlín) (fig. 15). Los rasgos fisonómicos de personajes reales atribuidos a los reyes obligan a dar nuevos pasos, incluso en algunas producciones tardogóticas.

Pese a no obedecer a este último apelativo, no sería lógico concluir un artículo sobre Epifanías con donantes sin recordar el Tríptico de la Epifanía del Bosco (fig. 16), una de las adoraciones de

${ }^{56}$ Me ocupo de algunas de estas cuestiones en: Alcoy, Rosa, "La sortija y el martillo de Francesco d'Este. Notas sobre un retrato atribuido a Rogier Van Der Weyden”, Materia. Revista d'Art, n. 6/7 (2006-2007), pp. 63-99 y en el libro Anticipaciones del paraíso... 


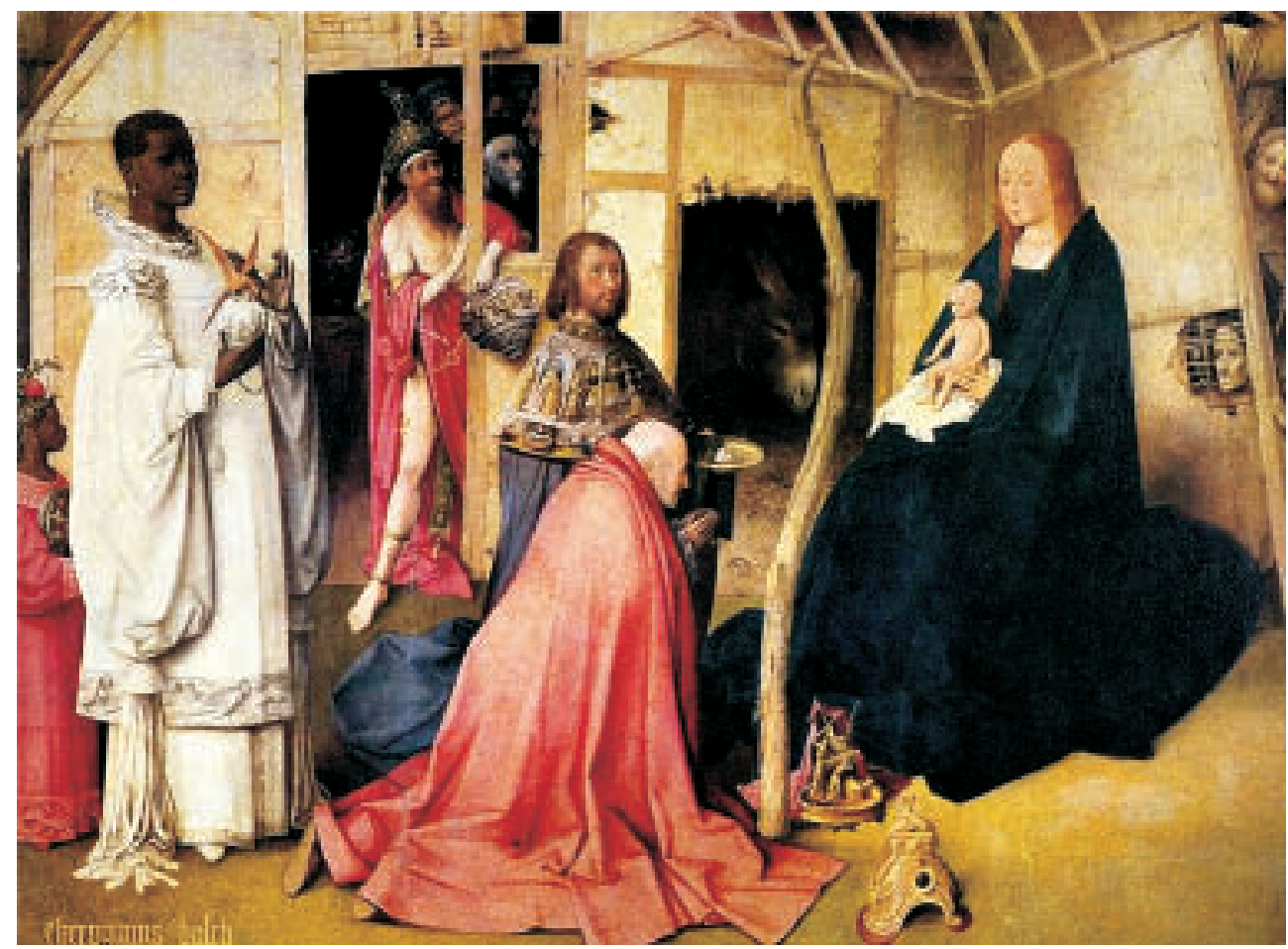

Fig. 18. El Bosco, Detalle de la Epifanía del Tríptico de los reyes Magos, Madrid, Museo Nacional del Prado.

los magos más célebres de la historia de la pintura, en que el pintor del Brabante se hace eco de una tradición consolidada. El conjunto del Museo del Prado remoza los argumentos medievales a través de su profundo conocimiento de la cultura y la pintura flamenca. La antigua fórmula devocional alusiva a los donantes y a sus santos patrones se encaja en las alas del tríptico, irreprochablemente integrada en los esquemas de un pintor innovador que tiene a sus espaldas toda la Edad Media. Los donantes, acomodados en sus batientes y presentados por sus santos patrones y abogados, resultan ser nuevos aprendices de los buenos magos -de los tres grandes reyes magos- frente a un mundo que amplía sus registros pero en el que la locura, el mal, la sinrazón o la brujería van a florecer sin remedio, avanzando el dolor que sigue al tema del gozo y que ha sido resumido en la Misa de san Gregorio (fig. 17). Este tema eucarístico asociado a la Pasión se contempla cuando el tríptico está cerrado. Sin embargo, todo parece anunciado ya en la Epifanía central por el enigmático y polémico personaje que asoma galas y desnudez desde el fondo. Es el llamado por algunos "cuarto rey", un símbolo elocuente de la locura y del loco i(fig. 18)?, que podemos entender mucho mejor como modelo de los malos aprendices, de los estúpidos y de todos aquellos que fueron incapaces de comprender, y seguir, el ejemplo de los reyes magos.

Fecha de recepción: $1-\mathrm{X}-2008$

Fecha de aceptación: 3-VII-2009 